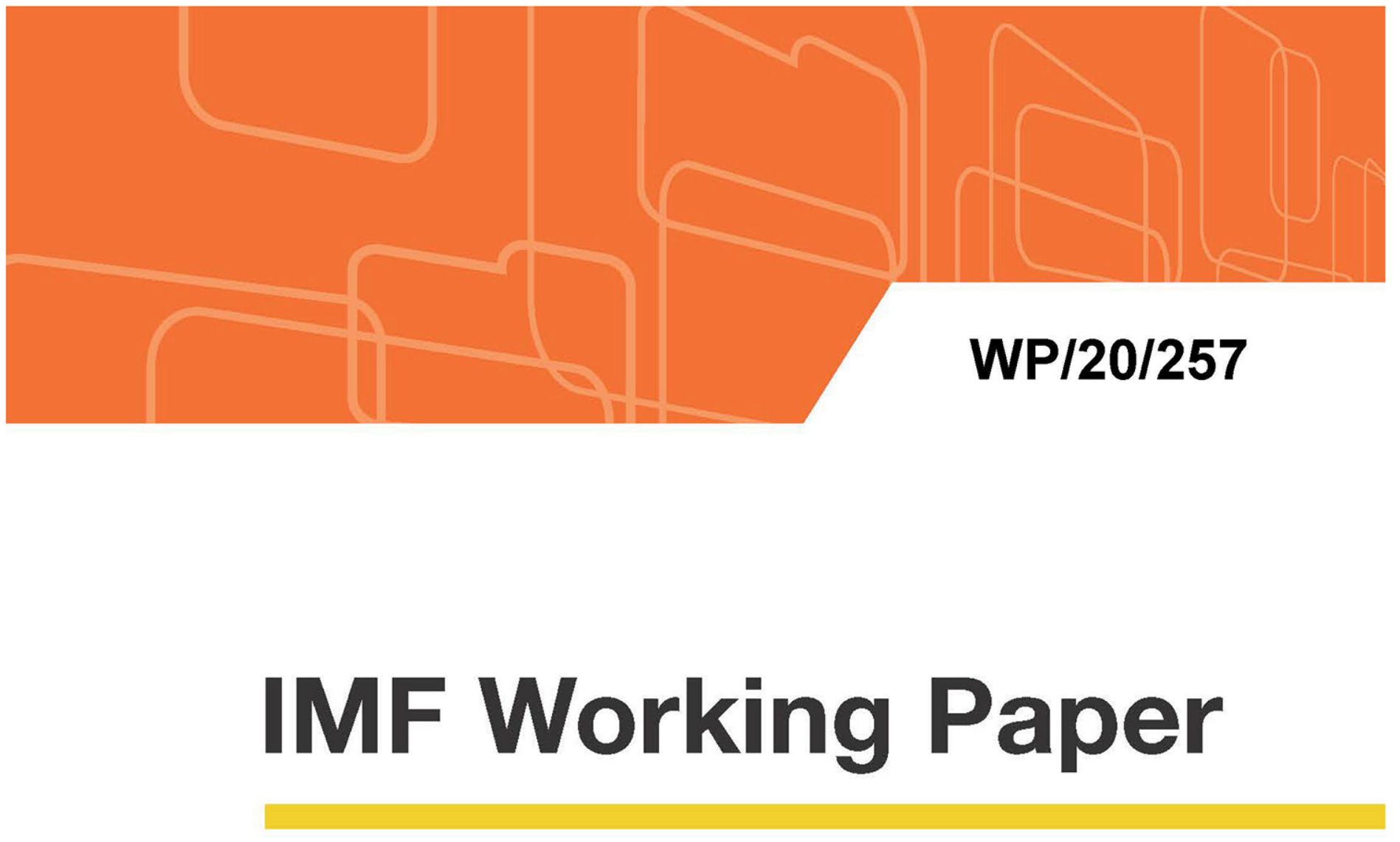

\title{
LOCAL CURRENCY BOND MARKETS LAW REFORM:
}

A methodology for emerging markets and developing economies

by Wouter Bossu, Cory Hillier, and Wolfgang Bergthaler

IMF Working Papers describe research in progress by the author(s) and are published to elicit comments and to encourage debate. The views expressed in IMF Working Papers are those of the author(s) and do not necessarily represent the views of the IMF, its Executive Board, or IMF management. 


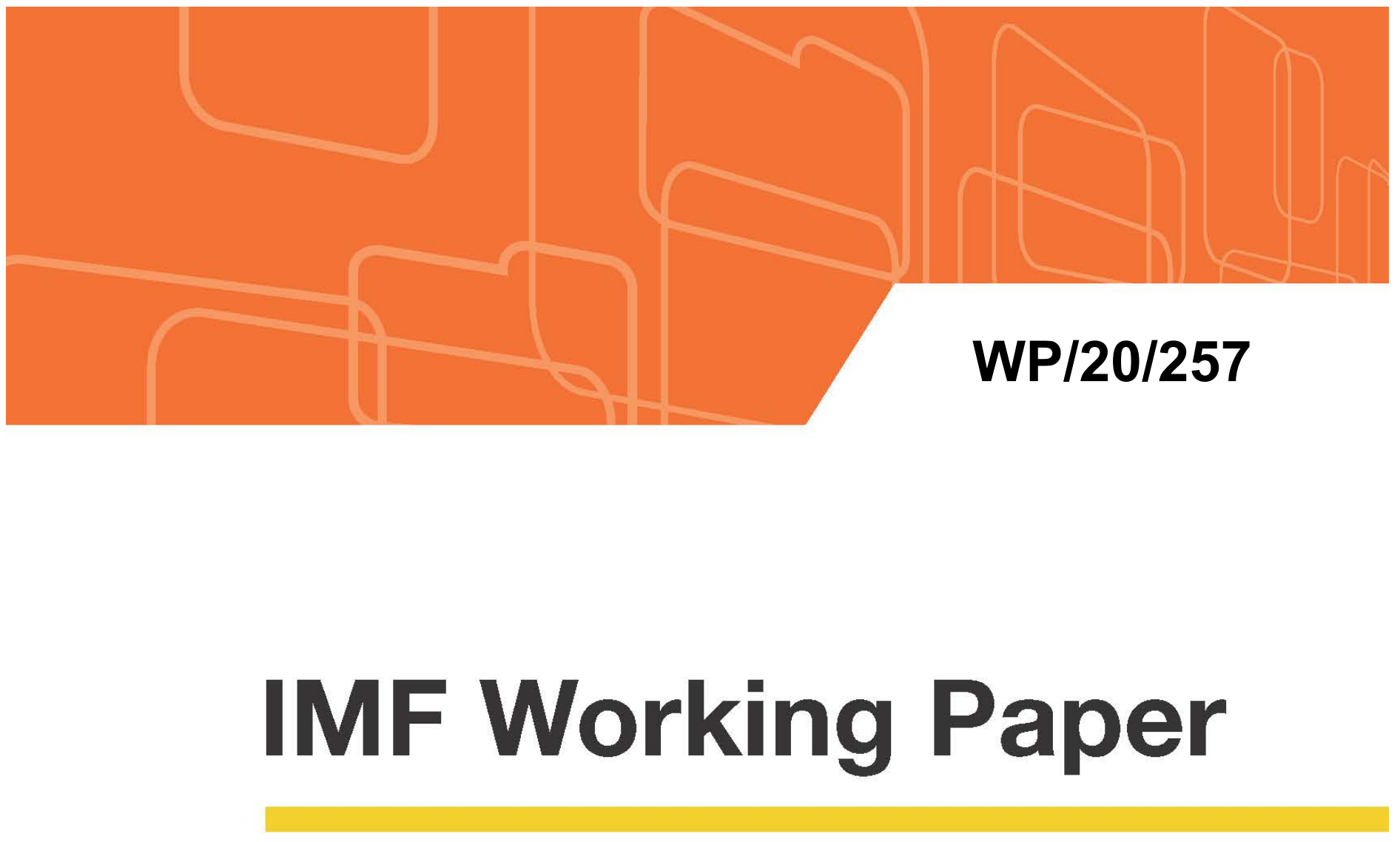

\section{LOCAL CURRENCY BOND MARKETS LAW REFORM:}

\section{A methodology for emerging markets and developing economies}

by Wouter Bossu, Cory Hillier, and Wolfgang Bergthaler

IMF Working Papers describe research in progress by the author(s) and are published to elicit comments and to encourage debate. The views expressed in IMF Working Papers are those of the author(s) and do not necessarily represent the views of the IMF, its Executive Board, or IMF management. 


\title{
IMF Working Paper
}

\author{
LEG
Local Currency Bond Markets Law Reform: A Methodology for Emerging Markets and Developing Economies \\ Prepared by Wouter Bossu, Cory Hillier and Wolfgang Bergthaler \\ Authorized for distribution by Yan Liu
}

November 2020

\section{IMF Working Papers describe research in progress by the author(s) and are} published to elicit comments and to encourage debate. The views expressed in IMF Working Papers are those of the author(s) and do not necessarily represent the views of the IMF, its Executive Board, or IMF management.

\begin{abstract}
Recent financial crises including the ongoing one caused by the COVID-19 pandemic have consistently drawn attention to the need to strengthen the quality of public debt management in emerging markets and developing countries. Deeper and more efficient domestic government debt markets - being, a key segment of the LCBM for many emerging markets and developing economies - play a key role in reducing financial vulnerability to shocks and enable governments to finance critical economic and fiscal policy measures in response to them. Policymakers and international organizations have long recognized that developing and strengthening LCBMs is a key policy prescription to sound public debt management. Robust legal and regulatory frameworks are recognized as being critical building blocks for the structure, development and functioning of LCBMs. This Working Paper seeks to outline a strategically anchored methodology that can be applied to design, build and implement the legal and tax foundations for the development of LCBMs that would adequately address common challenges and impediments.

JEL Classification Numbers: G15, G18, G23, G34
\end{abstract}

Keywords: local currency bond markets, capital markets, development, financial stability, legal and tax frameworks

Authors’ E-Mail Addresses: wbossu@imf.org, chillier@,imf.org,wbergthaler@imf.org 


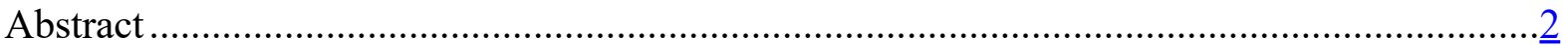

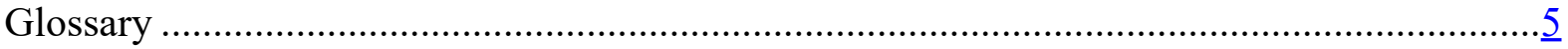

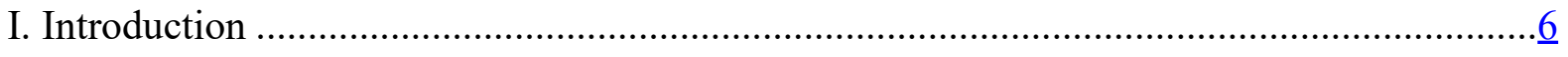

II. LCBM: the Legal Mandate and Role of the IMF .......................................................

III. Overall Sequencing of Law Reform Initiatives .................................................13

IV. The Institutional Framework for the Market …..................................................... 19

V. The Issuance: Authorization to Issue Debt Instruments ......................................... 20

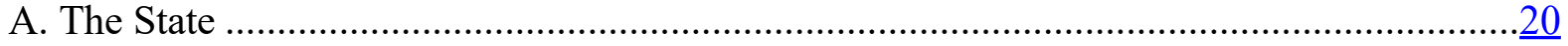

B. Other Public Bodies ............................................................................................ 22

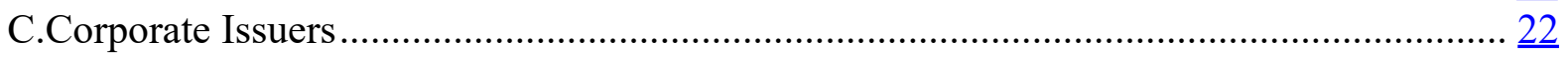

VI. The Substance and Form of the Securities …..................................................... 22

A. The Substance: Contractual Framework of Local Currency Bonds ............................... 22

B. The Form: Dematerialized Securities Holding Legislation............................................28

VII. The Use: Secondary Market and Collateral Transactions ......................................... $\underline{31}$

A. Outright Sales/Purchases................................................................................... $\frac{31}{31}$

B. Financial Collateral Law .......................................................................................... $\frac{31}{33}$

C. Central Bank Monetary Policy Legal Framework ....................................................... $\underline{33}$

VIII. Tax Treatment of Primary and Secondary Market Transactions ................................. $\underline{34}$

A. Supply side treatment — primary and secondary market ….....................................

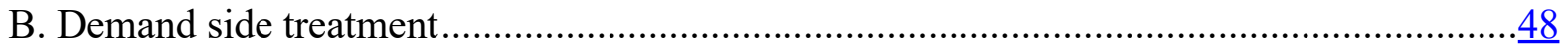

IX. The Post Trading: Settlement Finality Law .........................................................

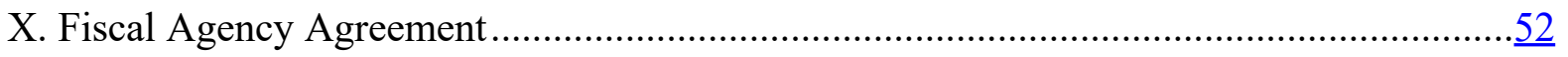

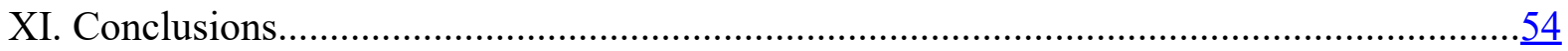

Boxes

1. IMF's Approach to Capital Account Liberalization and LCBMs ...................................12

2. Typical Clauses for General T\&Cs of Local Law Government Bonds ..............................24

3. Collective Action Clauses in Local Law Governed Bonds ...........................................25

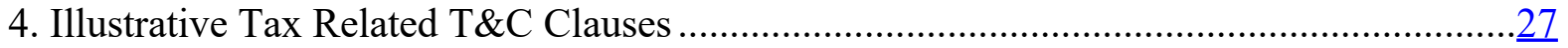

5. Objectives of Supply Side and Demand Side Tax Reforms ….................................... $\underline{35}$

6. Tax Treatment Issues to be Addressed by the Tax Law Framework: Supply Side............. $\underline{36}$

7. Sample Legislative Provisions: Securities Lending Arrangements ................................. 45

8. Key Tax Treatment Considerations for Repos................................................................ 47

9. Sample Legislative Provisions: Repo Arrangements.................................................. 48

10. Tax Treatment Issues to be Addressed by the Tax Law Framework: Demand Side......... $\underline{50}$ 
11.Settlement Finality Legislation

\section{Tables}

1. Baseline Tax Law Treatment of LCBs comprising government debt securities

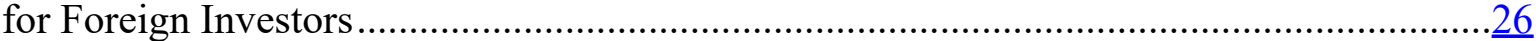

2. Baseline Tax Law Treatment of LCBs comprising government debt securities for Local and Foreign Investors .....................................................................

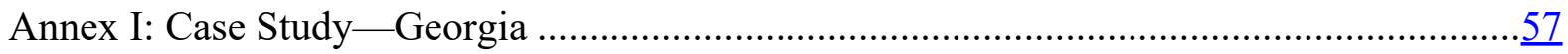

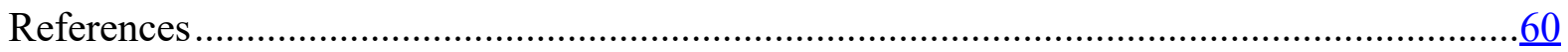




\section{Glossary}

\begin{tabular}{|c|c|}
\hline $\mathrm{ADB}$ & Asian Development Bank \\
\hline $\mathrm{CCP}$ & Central Clearing Counterparty \\
\hline CIS & Collective Investment Scheme \\
\hline CSA & Credit Support Annex \\
\hline CSD & Central Securities Depository \\
\hline DVP & Delivery versus Payment \\
\hline EBRD & European Bank for Reconstruction and Development \\
\hline EU & European Union \\
\hline FMI & Financial Market Infrastructure \\
\hline FX & Foreign Exchange \\
\hline GN & Guidance Note \\
\hline GMRA & Global Master Repurchase Agreement \\
\hline GMSLA & Global Master Securities Lending Agreement \\
\hline G20 & Group of Twenty \\
\hline IFAWG & G20 International Financial Architecture Working Group \\
\hline $\mathrm{IM}$ & Information Memorandum \\
\hline IO & International Organization \\
\hline IOSCO & International Organization of Securities Commissions \\
\hline ISDA & International Swaps and Derivatives Association \\
\hline ISIN & International Securities Identification Number \\
\hline LCBM & Local Currency Bond Market \\
\hline IMF & International Monetary Fund \\
\hline $\mathrm{MoF}$ & Ministry of Finance \\
\hline MTM & Mark-to-Market \\
\hline OECD & Organization for Economic Co-operation and Development \\
\hline OTC & Over-The-Counter \\
\hline PDs & Primary Dealers \\
\hline SFL & Settlement Finality Legislation \\
\hline SLA & Securities Lending Agreement \\
\hline SOE & State-owned enterprise \\
\hline TA & Technical Assistance \\
\hline $\mathrm{T} \& \mathrm{Cs}$ & Terms \& Conditions \\
\hline WBG & World Bank Group \\
\hline
\end{tabular}


INTERNATIONAL MONETARY FUND

\title{
Local Currency Bond Markets Law Reform: A Methodology for Emerging Markets and Developing Economies
}

\author{
Working Paper \\ Wouter Bossu, Cory Hillier and Wolfgang Bergthaler ${ }^{1}$
}

\section{INTRODUCTION}

1. Recent financial crises including the ongoing one induced by the COVID-19 pandemic have drawn attention to the quality of public debt management in emerging markets and developing countries. In this context, the current crisis has seen emerging markets and developing countries issuing more debt in global financial markets, with each crisis before it also having demonstrated the role that a deeper and more efficient local currency bond market (LCBM), and domestic government debt market in particular, can play in reducing financial vulnerability to shocks and enabling governments to finance critical economic and fiscal policy measures in response to them. Policymakers and International Organizations (IOs) have long recognized that developing and strengthening LCBMs is a key policy prescription to sound public debt management. The literature on LCBM development generally defines specific preconditions and six key building blocks for market development. ${ }^{2}$ As they affect the structure and functioning of LCBMs, the legal and regulatory frameworks are one of these six key building blocks, thereby making those frameworks critical to the development of LCBMs.

\section{This Working Paper seeks to outline a strategically anchored methodology to strengthen the legal and tax foundations for the development of LCBMs. Specifically,}

\footnotetext{
${ }^{1}$ The authors would like to sincerely thank IMF colleagues and external reviewers for their input and comments to this Working Paper, including Elsie Addo Awadzi (BoG), Catherine Bridge Zoller (EBRD), Joseph De Wolf, Viva Hammer, Alexander Klemm, Jacek Kubas (EBRD), Nicholas McBride (ADB), Tomas Magnusson, Onenne Partsch (BCL), Guilherme Pedras, Bart Servaes (World Bank Group), Keng Sim (ADB), Michael Strauss (EBRD), Elena Sulima (EBRD), Stefan Theys (Belgian Debt Agency), and David Abesadze and Tamar Kusikashvili (NBG, Georgia).

${ }^{2}$ IMF/World Bank Group Guidance Note for Developing Government Local Currency Bond Markets (forthcoming). The Guidance Note discusses the six building blocks that can be used to analyze and distinguish LCBM in terms of their depth, liquidity, diversity and resilience. These six building blocks comprise of: (i) Money Market; (ii) Primary Market; (iii) Secondary Market; (iv) Investor Base (v) Financial Market Infrastructure (FMI); and (vi) the Legal and Regulatory Framework [emphasis added]. The six building blocks are intuitively designed to provide focus on key reforms for the efficient functioning of LCBMs.
} 
the methodology should assist authorities in designing a medium-term law reform plan that is anchored in the broader capital market development strategy, while recognizing that sequencing is at the same time critical and challenging. As a prerequisite, the roles of the relevant stakeholders (mainly the government and the central bank) need to be well-defined. The LCBM legal framework also needs to capture the building blocks of relevance for the broader creation and development of domestic financial markets. To ensure the sound issuance and trading of government debt securities, the LCBM legal framework should also govern the primary and secondary markets in government securities. To this end, the legal framework should clarify the legal status of dematerialized securities, shield investors from insolvency of custodians, and prohibit and sanction inappropriate behavior by custodians (for instance, misuse of client assets) and intermediaries (in particular, improper trading practices, such as market manipulation and insider trading). It is also critical that the legal framework for taxation be appropriate for the development and efficient working of the LCBM. In particular, tax laws should encourage investment and liquidity in bond markets by ensuring: the appropriate treatment of repurchase transactions; the development of both the primary and secondary market; and a clear and effective tax treatment for each key class of investor that conforms to international good practices, including for foreign investors. In fact, the tax treatment of investment in the LCBM often becomes essential to establishing critical links between LCBMs and international financial market infrastructures (FMIs).

\section{In recognition of the importance of LCBMs, the Group of Twenty (G20)} countries first launched an LCBM Action Plan in 2011 to monitor and support LCBM activity. ${ }^{3}$ In line with the Action Plan, a recent Staff Note was prepared by the IMF and World Bank Group which provided an update on the current developments in relevant LCBMs, for both sovereign and corporate bond markets, as well as the role of foreign investor participation in LCBMs and the application of financial technology to LCBM development. ${ }^{4}$ The IMF and World Bank Group staff have also prepared a more detailed Guidance Note (to which the authors of this Working Paper contributed) on developing LCBMs for emerging markets and developing economies, which provides a broader framework (beyond legal foundations) that can be applied to strengthen each key foundation of LCBMs. As noted above, it specifically recognizes that robust legal and regulatory

\footnotetext{
${ }^{3}$ The action plan targeted three key areas for progress: (i) scaling up technical assistance (TA); (ii) developing a shared database to track relevant assistance; and (iii) monitoring annual progress. In 2013, the Fund and its partners (the World Bank Group, OECD and EBRD) issued a "Diagnostic Framework" to provide a tool for analyzing the state of development and efficiency of LCBMs. Since then, the IMF and World Bank Group have updated the G20 International Financial Architecture Working Group on progress to strengthen LCBMs in emerging markets and developing economies on a regular basis.

${ }^{4}$ Staff Note (IMF and World Bank Group) for the G20 International Financial Architecture Working Group (IFAWG) - Recent Developments on Local Currency Bond Markets in Emerging Economies, Washington, 2020.
} 
frameworks, including tax, are one of the six key building blocks for the development of LCBMs.

4. This Working Paper seeks to build on the Guidance Note by providing a more detailed discussion of legal frameworks necessary to develop LCBMs in emerging markets and developing economies. It does so by seeking to outline a framework that can be applied to strengthen the legal and tax foundations for the development of LCBMs, and to address common challenges and impediments to devising and implementing appropriate legal policy actions and translating them into implemented law reforms. Importantly, the LCBM and capital market more broadly will only develop after an appropriate balance has been struck by the underlying legal frameworks through, on the one hand, creating a relatively frictionless legal and tax environment for primary and secondary market transactions and, on the other hand, preserving the integrity and transparency of the market itself. Striking and maintaining this balance upfront will minimize the need for future fundamental policy or regulatory changes that can lead to market shocks that undermine the objective of deepening LCBMs through attracting and maintaining investors.

\section{While the Working Paper focuses primarily on government securities, it also} covers relevant aspects of corporate bond markets. It is well recognized that "there are two distinct phases of capital market development, an embryonic phase in which the government is predominant and a mature phase in which the capital market starts to serve the private sector." 5 This creates an obvious connection between the law reform plan relating to the government securities market and the corporate debt market which should be considered in parallel. However, this Working Paper does not consider the company law reform issues that are often needed to develop the corporate bond market, nor does it explore the necessary judicial reforms to support the efficient working of LCBMs. This said, while some of the topics covered (tax, fiscal agency) only apply to government debt, other topics (e.g., dematerialized securities holding) apply to both government and corporate debt securities.

6. Finally, there is no one-size-fits-all approach. This Working Paper draws on IMF staff's experience supporting law reform efforts to develop LCBMs in key capacity development engagements with IMF member countries (see Annex 1 for the case of Georgia). A key lesson of our experience is that the ultimate design and adjustments to a country's legal and tax foundations to develop their LCBM is dependent on their underlying legal framework and conditions, having regard to their overall capital markets development plan.

\footnotetext{
${ }^{5}$ IFC, EM Compass, Creating Domestic Capital Markets in Developing Countries: Perspectives from Market Participants: https://www.ifc.org/wps/wcm/connect/dacea4f3-17da-4f4b-943f-9b107dfe3be0/EMCompassNote+77-Creating+Domestic-Cap-Markets-Dev-Countries.pdf?MOD=AJPERES\&CVID=m.SUIvR
} 
7. This Working Paper is organized as follows: Section II discusses the IMF's legal mandate and role as it relates to LCBMs. Section III outlines the expected sequencing of law reform initiatives to develop LCBMs and capital markets more generally. Section IV discusses how the legal framework should allocate with clarity the various institutional roles between key stakeholders in the LCBM. Sections V, VI and VII are organized around a set of sequential and technical legal features that are necessary to provide a sound legal basis for the issuance of LCBs, covering both their form (legal status of dematerialized securities) and substance (contractual framework for public debt securities), as well as their use in secondary market and collateral transactions. Section VIII provides detailed guidance with respect to developing an appropriate legal framework for taxation, which is equally critical for the development and efficient working of the markets in government securities. Sections IX and $\mathrm{X}$ discuss two remaining specific and technical legal features that are necessary to support post-trading and settlement of LCBs. Section XI then concludes with a summary of the key legal and tax foundations that would adequately address common challenges and impediments to support the development of LCBMs.

\section{LCBM: THE LEGAL MANDATE AND ROLE OF THE IMF}

\section{As the institution at the center of the international monetary and financial} system, the IMF's interest in LCBMs is grounded in its legal mandate to promote 'exchange stability,' which ranks among its purposes (Article I of the IMF's Articles of Agreement (the IMF's Articles)). ${ }^{6}$ In the context of its functions (such as surveillance under Article IV), the IMF focuses on those policies of members that can significantly influence present or prospective balance of payments and domestic economic stability. These policies include exchange rate policies, monetary, fiscal, and financial sector policies. ${ }^{7}$ The size and key features (e.g., currency composition and maturity) of a country's debt and the mechanisms through which that debt is financed are hence very important for the IMF. Moreover, IMF staff also shares general policy advice on debt management, which in respect of LCBM it has channeled mainly through the joint outputs with other IOs, at the request of the G20 (see above).

\section{A well-developed LCBM is also important for a country's macroeconomic} performance and financial stability, which also fits squarely within the IMF's mandate. A well-developed LCBM brings the prospect of the following potential benefits for a local economy: ${ }^{8}$ (i) increase of a country's ability to absorb volatile capital flows and intermediate

\footnotetext{
${ }^{6}$ Article I (iii) provides as a purpose "To promote exchange stability, to maintain orderly exchange arrangements among members, and to avoid competitive exchange depreciation."

${ }^{7}$ Decision No. 15203-(12/72), July 18, 2012 in IMF, 2019, Selected Decisions, p. 10 at https://www.imf.org/external/SelectedDecisions/Description.aspx?decision=15203-(12/72).

${ }^{8}$ IMF/World Bank Group Guidance Note for Developing Government Local Currency Bond Markets (forthcoming).
} 
them efficiently; ${ }^{9}$ (ii) reduction of the reliance on foreign borrowing and of the risks linked to currency mismatch; (iii) contribution to the reduction of current account imbalances; (iv) mitigation of the need for large precautionary reserve holdings; and (v) improvement of the capacity of macroeconomic policies to respond to shocks (G20 Cannes Summit, 2011). LCBMs also facilitate the development of broader capital markets and create longer term savings products. In this light, the underlying legal and tax frameworks that are required to support an effective and efficient LCBM cannot be underemphasized because of these macroeconomic impacts.

10. Further, from a financial stability perspective, the banking sector especially relies heavily on a well-developed LCB secondary market to manage its liquidity through repurchase and securities lending arrangements among others. The absence of well-developed LCBM, and therefore eligible collateral for repurchase and securities lending operations, is a significant impediment for banking sector stability as it affects banks' ability to effectively manage liquidity, and could even create risks for central banks' balance sheets when the latter have to accept less desirable collateral in the absence of LCBs or other government securities for emergency liquidity assistance purposes. As discussed further below, many public debt laws actually explicitly mandate governments to borrow not only for fiscal purposes but also for financial market development purposes. In this regard, the underlying legal and tax frameworks that are required to support an effective and efficient LCBM can support a country's macroeconomic performance and financial stability.

\section{The IMF's mandate in respect of the "multilateral payment system" is also} relevant. Another purpose of the IMF is 'to assist in the establishment of a multilateral system of payments in respect of current transactions between members and in the elimination of foreign exchange restrictions which hamper the growth of world trade. ' ${ }^{10}$ The more detailed legal rules with respect to limits on the payment and transfers for current international transactions are set forth in Article VIII, Sections 2 and 3 of the IMF's Articles. ${ }^{11}$ Under this provision, IMF members are prohibited, without the IMF's prior approval, from imposing restrictions on the making of payments and transfers for current international transactions. ${ }^{12}$ In ascertaining whether a measure is such a restriction, the guiding principle is whether the measure "involves a direct governmental limitation on the

\footnotetext{
${ }^{9}$ Non-resident investors are key to developing LCBMs, but can be more sensitive to global market conditions, which contribute to market volatility. This can give rise to the need for careful monitoring and robust safeguards in the form of available capital flow measures, where appropriate.

${ }^{10}$ See Article I (iv) under the IMF's Articles.

${ }^{11}$ Elizalde, H., The International Monetary Fund and Current Account Convertibility, Current Developments in Monetary and Financial Law, Vol. 4, 2005, pp. 17-40.

${ }^{12}$ They are also prohibited from engaging, or permitting any of its agencies to engage, in any discriminatory currency arrangements or multiple currency practices: see Article VIII, Section 3.
} 
availability or use of exchange as such." ${ }^{13}$ Subject to certain criteria, the IMF may approve the temporarily retention of measures imposed inconsistent with the member's obligations under Article VIII, Sections 2 and 3. In contrast, under the IMF's Articles, members are free to impose capital controls, provided these are consistent with the members obligations under Articles IV, Sections 1 and 3, and VIII, Sections 2(a) and 3 (IMF 2010; IMF 2012). ${ }^{14}$ Under Article VI, Section 3 of the IMF's Articles, IMF members may exercise such controls as are necessary to regulate international capital movements, but no member may exercise these controls in a manner that will restrict payments for current international transactions. ${ }^{15}$

\section{Specifically, some aspects of LCBM fall directly under the IMF's "current} account jurisdiction." Article XXX(d) of the IMF's Articles includes in its definition of "payments for current transactions" also "payments due as interest on loans" and "payments of moderate amount for amortization of loans," even though those transactions may be characterized as capital from an economic or financial reporting perspective. By consequence, while the acquisition by a non-resident of a bond in the country of origin amounts to a capital account transaction, the payment of interest (coupons) and moderate amounts of amortization of the principal by the debtor to the foreign holder amounts to "payments for current transactions" covered by the IMF's Articles. As countries open up their current account legal framework, the manner in which they remove current account restrictions will have an impact on the legal framework for the participation by foreign investors in the LCBM. Specifically, the prohibition to impose current account restrictions (without prior approval by the IMF) is relevant for the "exit" of those investors through the transfer abroad of coupon payments and proceeds from repayment of moderate amounts of amortization repayments.

\section{Beyond the current account, the IMF also advises more broadly on capital} account liberalization, which is equally relevant. As the acquisition and sale of bonds and bills by non-residents in the primary and secondary markets are considered as capital account transactions, the liberalization of the capital account will determine when and how foreign investors can "enter" into and "exit" from the market. Since 2012, the IMF has an "institutional view" on liberalization and management of cross-border capital flows, which is summarized in Box 1. This view includes some specific reflections on LCBM.

\footnotetext{
${ }^{13}$ See: Decision No. 1034-(60/27), June 1, 1960 in IMF, 2019, Selected Decisions, p. 516 at https://www.imf.org/external/SelectedDecisions/Description.aspx?decision=1034-(60/27).

${ }^{14}$ The main legal framework governing this issue is enshrined, for OECD members, in the OECD Code of Liberalization of Capital Movements. This Code was recently revised and provides a balanced framework for allowing countries to progressively remove barriers to the movement of capital, while providing flexibility to cope with situations of economic and financial instability.

${ }^{15}$ See Leckow, R., Rendak, N., and Strauss, M., Currency Controls, Max Planck Encyclopedia of Public International Law, para. 7.
} 


\section{Box 1. IMF's Approach to Capital Account Liberalization and LCBMs}

Well-designed capital flow liberalization can help countries realize the benefits of capital flows, forgo the costs of "capital flow measures," and support key economic objectives (IMF, 2012). The benefits of liberalization are largest when countries have achieved certain levels of financial and institutional development. In particular, in order to strengthen countries' capacity to absorb and manage inflows and outflows, their financial systems need to be able to mediate flows safely, allow firms to access capital to finance productive investment, and give households and firms the ability to diversify their portfolios while managing the risks. Their institutions need to bolster the resilience of financial, corporate, and household balance sheets. Country experiences suggest that liberalization is more likely to be successful if it is supported by sound fiscal, monetary, and exchange rate policies. Exchange rate flexibility can help cushion the real economy against the effects of capital flow volatility. Greater trade openness can support liberalization by raising countries' ability to attract foreign capital and by supplementing domestic demand with external demand, which can mitigate the growth and financial effects of crises.

At the same time, capital flow liberalization carries risks, which are magnified when countries have yet to attain sufficient levels of financial and institutional development. The risks include heightened macroeconomic volatility and vulnerability to crises. In the absence of adequate financial regulation and supervision, financial openness can create incentives for financial institutions to take excessive risks, leading to more volatile flows that are prone to sudden reversal.

There is no presumption that full liberalization is an appropriate goal for all countries at all times. The degree of liberalization appropriate for a country at a given time depends on its specific circumstances, notably its financial and institutional development. At the same time, careful liberalization can provide significant benefits, which countries could usefully work toward realizing over the long run. Moreover, a country could make progress toward greater liberalization before reaching all of the necessary thresholds for financial and institutional development, and indeed doing so may itself spur progress in these dimensions. Liberalization needs to be managed particularly cautiously if the threshold conditions are not yet met, as the risks are higher.

A range of policies is needed to reap the benefits of more open capital flows while managing the risks. Strengthening and deepening financial markets, and improving countries' institutional capacity, would help improve their ability to handle capital flows. Capital flows, both inward and outward, generally warrant adjustments in macroeconomic variables, including the real exchange rate, and policies need to facilitate these adjustments. Volatile capital flows can give rise to macroeconomic and financial stability risks. Policies of countries from which capital flows originate are also relevant, since flows are influenced by both push and pull factors. A key challenge for many economies is to have in place the policies and institutional setup to effectively absorb inflows and channel them toward productive investment. Inflows can help supplement domestic saving to finance domestic investment, entail technological spillovers, and expand trade finance. Surges of inflows can pose problems for policymakers. Surges can lead to financial and macroeconomic volatility by overwhelming domestic financial markets and stretching the capacity of macroeconomic policies to adjust. 


\section{Box 1. IMF's Approach to Capital Account Liberalization and LCBMs-Cont'd}

Capital outflows that are large, sustained, or sudden can pose significant policy challenges. Some capital outflows are a natural consequence of openness, as foreign investors recoup their investments and domestic investors diversify their portfolios and expand business operations abroad. Outflows can, however, become disruptive in some circumstances, which are usually associated with economic crises. Such disruptive outflows can be driven by domestic factors, but they can also be driven by international factors such as global risk appetite, liquidity, interest rates, and global growth, and by contagion effects through trade and financial linkages and investor confidence. Building economic and financial resilience is important for withstanding and managing capital outflows safely. Outflows should usually be handled primarily with macroeconomic, structural, and financial policies. In crisis situations, or when a crisis may be imminent, there could be a temporary role for the introduction of capital flow measures on outflows. Introducing outflow CFMs should always be part of a broader policy package that also includes macroeconomic, financial sector, and structural adjustment to address the fundamental causes of the crisis.

In relation to LCBMs specifically, the IMF's institutional view points out that local bond markets that are well developed and integrated can facilitate the raising and intermediation of non-resident investment. The view however stresses that sound regulation and oversight of LCBMs, ideally combined with steps to deepen the markets, ought to be a precondition for opening up to foreign investors.

\section{OVERALL SEQUENCING OF LAW REFORM INITIATIVES}

\section{The capital markets usually develop sequentially in emerging markets and} developing economies. The capital markets in those countries are expected to develop over time, and offer a variety of securities and transactions in broadly the following order:

- $\quad$ Firstly, Foreign Exchange (FX). Certainly for (relatively) open economies, it is expected that the basic precursor to the development of a country's capital market is the organization of its FX market. This should be supported by a well-sequenced opening of the current and capital account (see Box 1).

- $\quad$ Secondly, debt securities. Many markets often already offer basic fixed income securities (typically denominated in local currency), including government bonds (and bills) or LCBs and central bank bills. It is conceivable that, with supportive legal settings, secondary sales of debt securities would also increase over the short term, making the initial parallel establishment of over-the-counter (OTC) secondary markets equally important. This Working Paper is focused specifically on LCBs as a subset of these debt securities. ${ }^{16}$

\footnotetext{
${ }^{16}$ Banking and other financial sector issues are also important with respect to the development of LCBMs and the underlying legal and tax frameworks. For instance, banks invariably hold a substantial proportion of LCBs for good reason, and it creates a captive market for such bond issuances. Holding LCBs are often good for
} 
- Thirdly, FX and interest rate derivatives, financial collateral, securities lending and repurchase (or repo) transactions. These transactions could develop over the short to medium term and are expected to be initially related to debt securities. Some repo transactions over government debt securities commonly occur at a very early stage in the banking sector. This Working Paper provides guidance in relation to the legal and tax foundations necessary to further develop and deepen the secondary market in LCBs.

- $\quad$ Finally, equity securities, which may or may not be registered or listed on a local exchange (whenever one exists) or any other jurisdiction, including common stock/shares. The ordinary equities market (long trading) will often be established earlier, but it is expected to more fully develop and deepen over the medium to long term (for instance, emergence of short trading and related derivative transactions), with such related products including options, securities lending, convertible bonds, hybrid securities and preferred shares. Equity securities are beyond the scope of this Working Paper (although as discussed below the guidance provided with respect to the legal and tax foundations necessary to develop the primary and secondary market in LCBs will also be applicable for the development of equity markets).

banks as they are typically high-quality assets that are advantageous for a capital adequacy ratio computations, as well for meeting other prudential ratios such as high-quality liquid asset and other liquidity ratios. This said, concentrated holdings of LCBs on a bank's balance sheets could impact on their capacity to lend to the private sector (financial repression) and an overexposure could lead to vulnerabilities in the event of a debt restructuring. Similar considerations may apply mutatis mutandis to the insurance and pension fund sectors. 
15. The above-mentioned sequencing of capital market development is illustrated at a high level by the following flow charts.

\section{Stage 1 $\mathrm{FX}$ \\ Organization of basic core of FX market \\ - Based upon well-sequenced opening of current and capital account \\ - With due regard for pre-conditions}

\section{Stage 2 \\ Debt Securities}

- Fixed income securities, including corporate bonds and sovereign debt

- G20 focus on development of local currency bond markets

\section{Stage 3 \\ Secondary \\ transactions over \\ debt securities}

Outright sale, derivatives, securities lending, repos

(critical for hedging and liquidity)

- Initially related to debt securities

- Repo transactions over government debt securities often common, even in less developed markets

\section{Stage 4}

\section{Equity securities}

Initial focus on common stock/ordinary shares (often first established in earlier stages)

- This market develops over the medium to long term

- Development of related derivative products:

- Options;

- Securities lending;

- Convertible bonds;

- Hybrid securities and preferred shares. 


\section{The underlying legal and regulatory frameworks underpinning each of those stages of capital market development also need to be sequenced appropriately. Broadly speaking, it is possible to conceptualize the said framework as a pyramid with three layers (see diagram below):}

- $\quad$ The first, most basic layer includes the building blocks for the legal foundation of the capital market: the laws governing the enforcement of contracts (for instance, how to enforce monetary obligations incorporated in bonds, with simplified legal aspects of proof and enforcement?); property (for instance, how rights over property will be enforceable against third parties?); insolvency (for instance, how to settle competing claims when the debtor's liabilities exceed its assets?); and company law (for instance, how can economic agents with a capital surplus contribute, in the form of equity stakes, to those with a capital need?). Ultimately, these bodies of law will only be as strong as the quality of the judiciary charged with enforcing them. Taken together, this is a manifestation of the concept of the "rule of law." 17

- $\quad$ The second, middle layer covers a broad gamma of legal instruments that relate to how financial assets are issued, acquired, held, exchanged, exercised, reported and taxed. In addition to the: (a) financial audit and reporting; and (b) tax law frameworks, it includes rules on: (c) market access (for instance, exchange controls, pensions funds, insurance); (d) financial market infrastructure (for instance, settlement finality, custody, dematerialized securities holding, collateral); (e) monetary policy (for instance, which securities can be exchangei.e. monetized - for central bank liquidity?); and (f) banking, insurance and pension fund regulation (for instance, which securities can be held by banks to transform the maturity of deposits and against which capital cost?).

- $\quad$ The third, top layer is the legal framework that establishes and governs the operation of regulated securities markets. This includes: the organic framework of the securities regulator; the conditions for access to regulated primary securities markets; business conduct rules for transactions in the secondary markets; and continuous obligations for firms that have issued in the regulated markets.

\footnotetext{
${ }^{17}$ There is a strong connection between the government securities market and the corporate debt market which should be considered in parallel. In the context of the corporate debt market, this requires the underlying legal framework to have features ensuring: (i) the sacrosanct nature of the corporate veil; (ii) appropriate insolvency law settings which should allow for the orderly unpacking of debts which are unpaid, and the possibility of restructuring corporate debts; (iii) lending and borrowing in good faith, with a familiar term sheet; and (iv) the ability for lenders to lend collectively to a large business borrowers (i.e., a pooling of investors).
} 


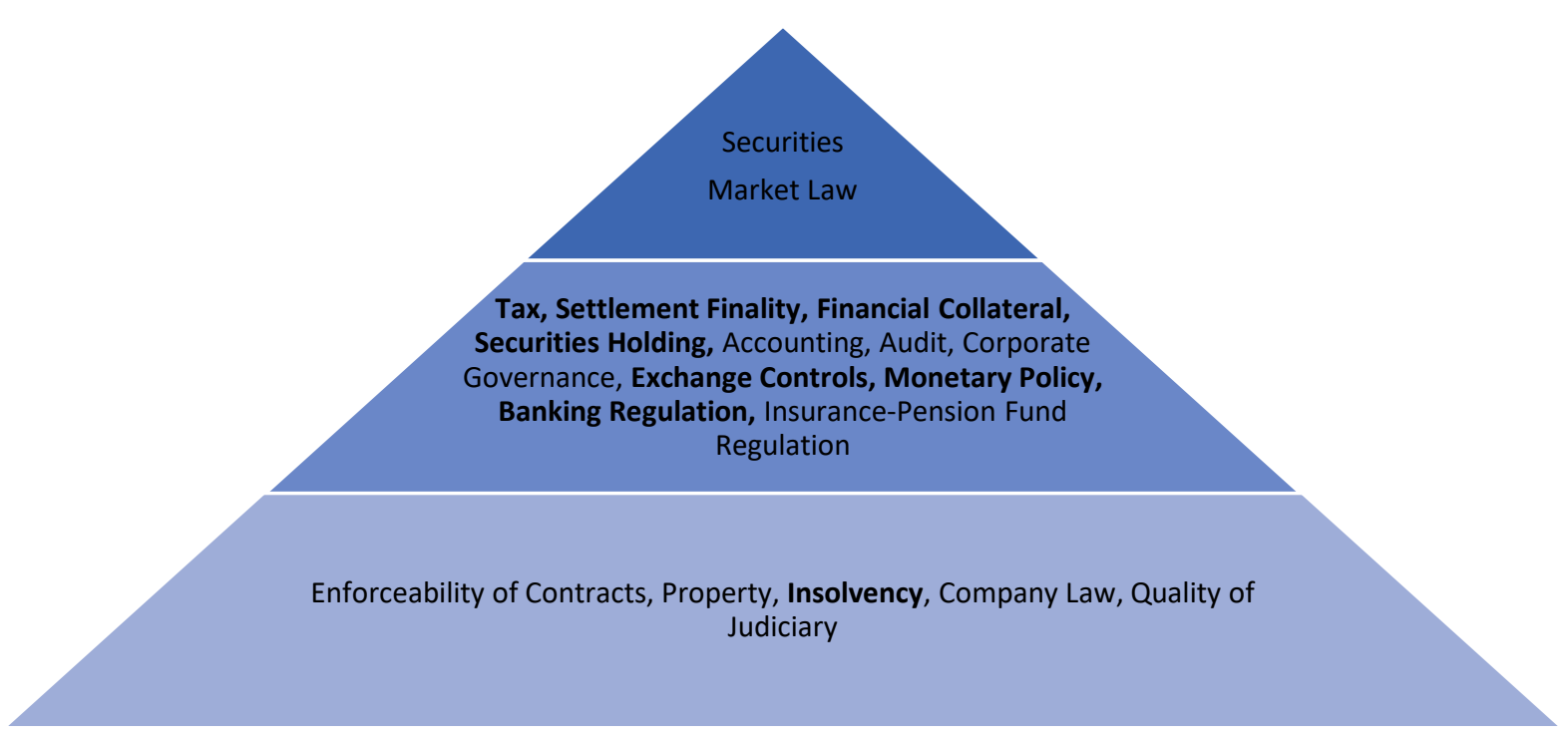

17. The underlying ideas are two-fold. First, the legal framework for capital markets is broad and multifaceted, and each component plays its own critical role. Second, for each layer to work, the underlying layer(s) must also work effectively. ${ }^{18}$ As can be seen in some developing markets, the best securities markets law will do little to spur market development if the country does not have an effective legal framework and respect for the rule of law. Moreover, law reform can be a complex and arduous process: often international best practice will remain aspirational for the top layer, which pleads for focusing first on the basic and middle layer of the pyramid. At the same time, the law reform needs to be designed in a manner that creates a relatively frictionless legal and tax environment for primary and secondary market transactions (including, foreign to foreign transactions over LCBs) while at the same time preserving the integrity and transparency of the market itself. For example, in the context of LCBs, the respect for the overarching rule of law to bring about market certainty and investor protection also needs to be complemented by the integrity and transparency of the underlying market operations themselves - for instance, the way in which an interest rate is constructed and supported (e.g. objective determination of fixed or floating rates, and relevant local indices), and appropriate comfort that the debt on issue will not simply be inflated away. This advocates for a comprehensive and holistic approach to capital market law reform, as well as proper sequencing.

\section{Importantly, the sequencing of law reforms will not fully map the broader} sequencing of the development of the capital market. More specifically, many of the legal building blocks in the second layer of the pyramid will apply to several, if not all, of the phases of broader capital market development. For instance, the rules on settlement finality will be useful for all the 4 stages of development. Similarly, tax rules on transactions in, and income and gains derived from, securities, will be relevant for stages $2-4$. Further, while

\footnotetext{
${ }^{18}$ Of course, other non-legal issues will equally be important, such as sound public finances, low inflation, and a transparent exchange rate regime.
} 
equity securities (stage 4) are beyond the scope of this Working Paper, many aspects are also of relevance for non-governmental securities. Therefore, the guidance provided with respect to the legal and tax foundations necessary to develop the primary and secondary market in LCBs will also be applicable for the development of equity markets (e.g. legal infrastructure for the issuance, holding and circulation of dematerialized securities, as well as transactions related to equity securities such as short selling, securities lending, and use of those securities as financial collateral). ${ }^{19}$ That said, however, primary and secondary markets for nongovernmental securities also involve different stakeholders in terms of issuance, investors and transactions. This gives rise to some challenges: while the similarity of these markets for public and private sector securities rest on the same foundational concepts, they still need to be defined differently. This, in turn, may call for a clearer allocation of (regulatory, operational and supervisory) roles for both public and private securities.

\section{As noted above, this Working Paper also draws on the IMF's experience in key technical assistance (TA) projects. The IMF's Legal Department staff provides, at the} request of the member countries, technical assistance on the development of a core set of financial and fiscal legal instruments that underpin the development of LCBMs and the development of a country's capital markets more broadly. The areas of law reform within the IMF's Legal Department sphere of expertise which are bolded in the above pyramid include: (i) tax (all key aspects); (ii) central banking, (iii) payments systems and FMIs, (iv) public debt securities; and (v) insolvency. It, however, excludes, for instance: (i) company law; (ii) securities market law; (iii) corporate governance; (iv) insurance law; (v) collective investment vehicles; and (vi) pension funds. There are also areas that the IMF can partially cover given the cross-cutting legal issues or otherwise guide the development of that work, which could, for example, consist of developing guiding principles on connected issues (for instance, authorization of issuance for corporate bonds and applicability of conduct of business rules to secondary market transactions in public debt securities). To ensure that the member country receives comprehensive law reform support, the IMF sometimes partners with other TA providers at the request of the member country so that the IMF law reform component can be combined and coordinated with other cross-cutting components (e.g. investment funds law support provided by another TA provider can be coordinated with IMF TA support to develop an investment funds taxation regime, and similar support by another TA provider to develop a derivatives law can be coordinated with IMF TA support to develop an accompanying taxation regime for derivative and financial collateral transactions etc.). Importantly, this is not an issue of competition with those other TA providers active in

\footnotetext{
${ }^{19}$ Although also not within the scope of this Working Paper, it is noted that a reasonably efficient real estate market is often the underpinning of all national wealth (against which LCBs are inherently supported) and, in turn, private wealth. Further, many secondary market transactions in a deeper capital market are derived from a well-functioning real estate market. For example, the ability to obtain a mortgage at a reasonable rate for a reasonable period (in a credible and transparent market) and the ability to use property as collateral (for instance, against investment loans) can be a key source of investment into capital markets and, in turn, leads to the development of many investment/securitization products such as mortgage backed securities.
} 
this area (for instance, the multilaterals such as EBRD and ADB, or sovereigns), but rather one of complementarity. Other TA providers focus on their core expertise (financial markets regulation, corporate governance, buy side development), and the IMF focuses on its core expertise: tax, public debt securities markets, settlement finality and collateral frameworks, and monetary policy frameworks. This complementarity and coordination have proven very effective in a number of country contexts (e.g. Georgia). ${ }^{20}$

\section{THE INSTITUTIONAL FRAMEWORK FOR THE MARKET}

\section{As a precondition for substantive law reform, the legal framework should} allocate with clarity the various institutional roles of key stakeholders in the LCBM. A detailed discussion of those roles goes beyond the scope of this Working Paper. However, to prepare for some of the discussions below, the following roles are highlighted:

- $\quad$ The State represented by the MoF-The State is the most important issuer in the LCBM. As such, the State will play a critical role in determining the structure of the primary and secondary (for instance, OTC v. stock exchange) markets for its local currency debt instruments. In the early stages of development, many States rely heavily on the central bank to manage their debt, whereas later on they increasingly develop their own capabilities, including through a public debt management office.

- Central Bank - The central bank plays an important role as fiscal agent of the State. In many countries, this function entails not only the payment of principal and coupon, but also assistance to the State in the primary market. The central bank also is a major user of LCB through its monetary policy framework. In some countries, the central bank will be an issuer of bills, which requires careful coordination with the MoF to avoid competition between issuances. Lastly, the central bank will operate and/or oversee critical market infrastructures in which LCBM transactions are settled (e.g., payment and securities settlement system).

- Market Authority - The market authority promotes fair and transparent financial markets generally. Typically, market authorities are less involved in the operation of the government debt securities markets than in those of private issuers, as the issuance of public debt is generally exempted from registration requirements. This said, the market integrity and anti-fraud rules that apply generally across the capital market should also apply to government debt securities markets.

- Central Securities Depositary (CSD) - The CSD plays a critical role in the settlement of LCB transactions. Often, the CSD will be operated by the central bank, at least for government bonds. If the CSD is operated by the private sector, it will often be

\footnotetext{
${ }^{20}$ https://www.ebrd.com/news/2020/georgian-parliament-passes-derivatives-law-supported-by-ebrd.html
} 
supervised by the market authority and the central bank. Its smooth interaction with the payment system of the central bank will be instrumental to minimize risks.

\section{The Issuance: Authorization to Issue Debt Instruments}

\section{The development of a sound LCBM is supported by legal certainty and clarity on the legal authorization of any entity intending to issue debt securities. ${ }^{21}$ Without such} an authorization, the legal validity of the issuance can be questioned. This may dampen investor interest in the issuance and more broadly raise concerns for investors, including with respect to the rating, eligibility for acquisition, and accounting treatment. While an implicit authorization may ultimately suffice in some circumstances should the legal authority ever be questioned, an explicit and clear authorization would be advisable in the case of public law issuers. Even in the context of corporations, questions may arise under company law whether a particular (type of) company is authorized to issue debt securities or not.

\section{A. The State}

\section{It is good practice to provide an explicit legislative authorization for the State to} issue bonds and bills. ${ }^{22}$ Such authorization is particularly advisable from the perspective of those legal systems that strictly follow the principle that the State and its agencies are allowed to do only what is directly permitted under their governing law. However, even for those legal systems that authorize bond issuance by the State under general principles of constitutional law, providing an explicit statutory authorization brings legal certainty and clarity. Such authorizing legislation can be the country's "public debt law" 23 - that is, the law codifying a comprehensive regime for public debt — or another, more specific legislative instrument, such as a law of public debt securities. ${ }^{24}$ The authorizing legislation will often combine the authorization to issue bonds with some procedural aspects, such as which political authority approves, on behalf of the State, the issuance. The authorizing legislation may also include rules on the form and other aspects of the bonds.

\footnotetext{
${ }^{21}$ This is actually part of the broader "mandate to borrow" discussed in Addo Awadzi, E., Designing Legal Frameworks for Public Debt Management, IMF, WP/15/174, paras. 39-44. The author also correctly notes that "(a) good legal framework will therefore not only provide for the authority to borrow, but also the authority to repay debt and related costs and expenses."

22 This authorization may actually be broader and include all types of debt instruments, including for instance the German-type Schuldschein. In this regard, a Schuldschein may not technically be considered to be "issued" as it is a kind of loan contract. It will be important for the law in emerging markets and developing economies to define the notion of "issue" in such a way that it also covers these sorts of arrangements, or otherwise ensure that these arrangements are legally authorized in order to avoid any legal uncertainties.

${ }^{23}$ For a good example, see Article 14.1 of the Law of Georgia on Public Debt.

${ }^{24}$ A good example is the Belgian law of 2 January 1991 on public debt securities.
} 
23. A consequence of an explicit authorization should be that all bonds and other debt securities issued in accordance with the authorizing legislation are valid obligations of the State. This entails, in particular, that debt limit rules have no impact on the legal validity of the bonds. There are countries where that is not the case. ${ }^{25}$

24. The public debt law should also include the longer-term objectives relating to debt management; the requirement to have a debt management strategy to achieve those objectives; and requirement to have an annual evaluation submitted to the Parliament/Congress. The objectives set out in that law sometimes include one to support the development of the domestic debt market. These objectives can be drafted using different legal language, but typically the relevant legislation has words to the following effect:

The objectives of State debt management are to ensure that: (i) the financing needs of the State always are met on a timely basis; (ii) its borrowing costs are as low as possible over the medium to long run, consistent with a prudent degree of risk; and (iii) development of the domestic financial market is promoted [emphasis added].

\section{To achieve the objective of promoting a well-functioning domestic financial} market, the debt management strategy would then include the actions of undertaking "planned borrowings and other debt management activities" for the express purpose of promoting the development of that market. Further, the relevant overarching strategy document normally includes: a plan to build up a yield curve in the domestic market by a regular supply of government securities (bills and bonds); progressive extension of the maturities; and consolidation of debt issues into a few liquid market benchmarks. In this regard, the scope of the LCBM also typically covers the money market (traditionally consisting of bills of up to one year), which are also very important in both developing economies and emerging markets. Sometimes countries issue treasury bills with maturities longer than one year, which will then overlap with the usual suite of LCBs. A strategic and consistent approach to developing a government securities market along various maturities/tenors with a transparent/market-based yield curve becomes very important. Here a trade-off has to be made between increasing the roll-over risk in building up liquid benchmark loans, and a better-functioning domestic debt market that will reduce the cost in the medium to long run. For the purpose of supporting the development of the domestic financial markets, countries also sometimes issue debt securities even if they run a fiscal surplus, just to ensure there are sufficient securities available for secondary market transactions, particularly for the banking sector (as discussed above).

26. Practically speaking, the issuance of government bonds and other debt securities should also be thoughtfully sequenced. For instance, it is often worthwhile first building a trusted public debt primary and secondary market through the successful issuance of more vanilla securities to gain investor confidence and then subsequently seeking to build off that

${ }^{25}$ See Addo Awadzi, E., o.c., para. 54 and footnote 80. 
success by expanding the market to other debt securities. Achieving a trusted public debt primary and secondary market that builds and maintains investor confidence also requires transparency with respect to public debt management such as periodic overviews of domestic fiscal data and overall public debt levels (at all relevant levels of government) which requires appropriate reporting and monitoring mechanisms, all of which typically requires the coordinated involvement of MoF/Treasury and the central bank.

\section{B. Other Public Bodies}

27. For other public bodies, it is similarly good practice to include an explicit authorization to issue bonds and bills in the foundational legislation of those bodies. Most public bodies are only authorized to do what the law explicitly or implicitly allows them to do. For sub-national governments, an authorization to issue bonds and bills could be included in the general law establishing and organizing those bodies, such as a Law on Municipalities. For State-owned enterprises (SOE), this authorization could be included in the organic law of the SOE in question, or in legislation governing SOEs (or a sub-category of SOEs) generally.

\section{Corporate Issuers}

28. Corporate issuers should have an explicit legal authorization to issue bonds and dematerialized commercial paper. (Historically, no such authorization was required for paper negotiable instruments, such as promissory notes.) Many legal systems limit the authorization to issue bonds and other debt securities to certain types of companies, mainly the ones akin to the French société anonyme. This is because the legislator considers other types of companies, such as cooperatives and companies for small businesses, to be too small, or have the wrong (ownership) structure, to seek funding from the capital markets.

29. There are a few options to provide this authorization. One option is to provide a blanket authorization in the company law or the civil code. Another option is to generally authorize the issuance in the company law, subject to an express authorization in the by-laws or articles of association of the company, as adopted by the shareholders, or through specific resolutions of the managing bodies (e.g. board of directors).

\section{The Substance And Form of The Securities}

\section{A. The Substance: Contractual Framework of Local Currency Bonds}

30. In many countries, local currency government bonds are not subject to a specific and well-calibrated contractual framework. Government bonds issued in foreign currency and governed by foreign (typically, English or New York) law will be subject to an elaborate set of contractual stipulations. For emerging markets and developing economies, this is often not the case for locally issued government bonds. This is not good practice, for a number of reasons. In relation to foreign investors, the absence of clarity and legal certainty on the 
contractual rights of bondholders will be an obstacle to attracting them. In relation to domestic investors, the lack of clear and appropriate contractual stipulations governing the most important asset of the financial system (in some cases together with central bank bills) will undermine the objective of developing financial markets and promoting good practices.

\section{The solution to this often-overlooked problem lies in the careful design of an} appropriate contractual framework for local currency government bonds and bills. There is no single best way of doing this. That being said, what is essential is a set of contractual General Terms and Conditions (T\&Cs) for the bonds and bills. ${ }^{26}$ In some countries, it will be useful to complement those with Specific T\&Cs for a specific bond or bill (typically identified by its ISIN code). Some sovereigns find it also useful to issue an Information Memorandum (IM) for their bonds. However, the boundary between information and legal provisions is sometimes not as clear as it could be in those documents-IM are more useful for disclosure than for contractual purposes.

\section{The legal design of such a contractual framework gives rise to a number of challenging and often fundamental legal questions. ${ }^{27}$ In countries of the Civil Law tradition, an important question will be how the General T\&Cs interact with Civil Code provisions on loan agreements. A second complex question concerns the interaction between contract and administrative law: some legal systems even have some form of "administrative contract law." In common law countries too, the design of T\&Cs may need to give due consideration to the common and statutory law rules governing loans of moneys.}

\section{The General T\&Cs need not be elaborate, but they need to include a number of} core provisions (see Box 2). The most important provision is the one on choice of law: a contractual clause should unequivocally establish that the bonds and bills are governed by the law of the issuing State. The second most important provision is the one on dispute settlement: the T\&Cs should establish that the local courts have exclusive competence, thereby excluding a role for foreign courts and arbitration tribunals.

\footnotetext{
${ }^{26}$ The General T\&Cs could be approved as such by the Minister of Finance. To ensure that these General T\&Cs apply to an issuance, the Term Sheet should ideally make specific reference to them.

${ }^{27}$ See also Bossu W., and Addo Awadzi E., Private Law Underpinnings of Public Debt Securities Markets, Uniform Law Review, 2013 Vol. 18, 2013, 564-588, Oxford Journals/Oxford University Press.
} 


\section{Box 2. Typical Clauses for General T\&Cs of Local Law Government Bonds}

- Definitions: e.g., of "issuer," "bonds," and "bills"

- Scope of Application: e.g., the T\&C would cover all local law governed bonds and bills issued by the issuer, but not necessarily non-negotiable debt instruments (such as Schuldschein) and certainly not foreign law-governed bonds

- Issuer: would be the State only, and not State-owned enterprises with separate legal personality or subnational governments (provinces, municipalities)

- Types of Securities: coupon bearing bonds and discount bills

- Nominal Amount of the bonds and bills

- Currency: in principle, only the currency of the issuer

- CSD and legal status under securities holding law (dematerialization): what is the legal form of the bonds and bills under applicable law and how are they held?

- Payment: how does the issuer pay coupon and principal? Does it stipulate whether an event of default occurs if there were a failure to pay principal, interest, or other amounts (such as any tax gross-up - see below) when due, after the expiration of any applicable grace period?

- Day Count and Business Day Convention: actual/360, actual/365 or actual/actual? What happens if a key date (such as payment or maturity date) is not a business day (e.g. paid on next business day, and whether unadjusted for additional interest)?

- Early redemption: possible or not?

- Notices

- Statute of limitation: follow the rule established by statute or impose contractually a specific term?

- Severability

- Tax: confirm whether payments in respect of the bonds will be made free and clear of withholding or deduction in respect of taxes (which is typically the case, especially for foreign investors). In the event that any payment is made subject to such withholding or deduction, no additional amounts will become payable by the issuer to the investor unless a contractual gross-up clause is agreed to be included in the T\&Cs (which should generally be resisted).

- Amendments

- Governing Law: will be exclusively the law of the issuer, to the exclusion of any foreign law element

- Dispute Resolution: will be exclusively the law courts of the issuer, to the exclusion of any foreign court or tribunal, including arbitration.

34. In contrast, there are other types of provisions that, while common in foreign law-governed bonds, are less expected in local law-governed government debt securities. Specifically, those T\&C may include additional provisions on the status of the 
bonds and bills, events of default and negative pledge clauses. ${ }^{28}$ While common in government bonds documentation under foreign law, these clauses are rather rare for local law-governed bonds. The same is valid for "collective action clauses," as discussed in Box 3.

\section{Box 3. Collective Action Clauses in Local Law Governed Bonds}

Should local law-governed General T\&Cs include Collective Action Clauses (CACs), which permit the key financial terms of a bond to be modified upon receipt of support of a qualified majority of bondholders holding a requisite percentage of the outstanding principal?

In 2014, the IMF endorsed key features of enhanced CACs only for international bonds (see IMF, 2014). However, the inclusion of CACs in local law-governed bonds may make unnecessary the need to retroactively modify the local law to introduce a statutory majority voting mechanism. The IMF has not endorsed this latter approach, but it has been used in the sovereign debt restructurings of Greece (2012) and Barbados (2017) (see IMF 2020).

Currently, the use of CACs in local law-governed bonds is limited. This said, it has been mandatory for all euro-area sovereigns' bonds with maturities of more than one year since January 1, 2013 (see paragraph 3, Article 12 of the ESM Treaty). ${ }^{1}$

To the extent CACs are used for local law-governed bonds, other clauses/issues such as uniformly applicable, information covenants, disenfranchisement would also need to be addressed.

${ }^{1}$ See: Model euro-CACs: https://europa.eu/efc/efc-sub-committee-eu-sovereign-debtmarkets/collective-action-clauses-euro-area/euro-area-model-cac en

\section{Tax certainty of treatment is also critical for holders of LCBs comprising government debt securities, especially foreign investors. Often the T\&Cs} (or accompanying IMs) are silent with respect to tax considerations. This is somewhat understandable because there are usually relevant tax concessions/exemptions in place (e.g. foreign investors are not taxed on gains, and interest withholding tax exemptions exist for coupon payments made to foreign holders, given both positions reflect international practice and represent the approach preferred by international FMIs). As discussed more comprehensively in section VIII below, the tax law settings applicable to LCBs need to be carefully integrated with the legal modalities relating to the issuance and trading of LCBs and the requirements of critical FMIs. While the ultimate tax treatment of a country's LCBs is a matter of domestic tax policy, having regard to their capital markets development plan, relief

\footnotetext{
${ }^{28}$ Some jurisdictions impose minimum requirements in relation to the definition of default for corporate bonds, while others leave this as a matter of negotiation.
} 
for foreign investors on LCBs comprising government debt securities (and sometimes, in appropriate circumstances, other publicly issued securities) is common international practice for a number of reasons, including: lack of enforceability where securities are held through chains of offshore custody structures; the coupon could be calculated to recoup the withholding tax levied at source or otherwise become subject to a contractual gross-up for withholding tax (which means the withholding tax is still borne by the issuer by increasing the government's borrowing costs, rather than the investor) ${ }^{29}$; and trading/capital gains could otherwise be structured to achieve treaty protection by holding the investment through a tax treaty country (given that tax treaties typically give the primary right to tax gains to the country of the investor's residence). For present purposes, a baseline tax treatment for nonresident investors reflecting common international practice with respect to the treatment of LCBs comprising government debt securities is set out in (Table 1) below. However, as noted above, the ultimate tax treatment of a country's LCBs is a matter of domestic tax policy, and countries remain free to tax either gains or returns on those securities where they choose to do so, subject to applicable tax treaties.

\begin{tabular}{|l|c|c|}
\hline \multicolumn{3}{|c|}{ Table 1. Baseline Tax Law Treatment of LCBs comprising Government Debt } \\
Securities for Foreign Investors
\end{tabular}

\section{However, when developing the $\mathrm{T} \& \mathrm{Cs}$, the legal policy aspects related to tax} continues to be raised during the course of IMF TA and, therefore, warrants further consideration (for instance, because other debt securities often have tax gross-up provisions such as corporate bonds, usually at the insistence of foreign investors). Although the final form of the T\&Cs will be shaped by the specificities of the country concerned, two baseline legal policy lines that could be considered with respect to LCBs comprising government debt securities are as follows (with Box 4 using the case of Australian Treasury Bonds to highlight how these baseline legal policy lines can be expressed in legal drafting):

\section{- Including a provision confirming that payments in respect of the LCBs will be} made free and clear of withholding or deduction in respect of taxes. This would also give foreign investors certainty with respect to returns, which becomes particularly important when foreign investors have no other connection with the issuing country other than investing in their LCBs; and

\footnotetext{
${ }^{29}$ Provided, in the case of a contractual gross-up, that this forms part of the terms and conditions of the LCB in question.
} 
- $\quad$ A provision confirming that, in the event that any payment is made subject to such withholding or deduction, that no additional amounts will become payable by the issuer to the investor (so as to not hamper the government with respect to future tax policy changes). However, it is noted that withholding tax would be very difficult to subsequently impose in practice in any case given FMI preferences (discussed above, and further elaborated in section VIII below) and adverse perceptions of sovereign risk by foreign investors in seeking to do so.

\section{Box 4. Illustrative Tax Related T\&C Provisions}

Australian Treasury Bonds have the following provisions:

\subsection{FEES}

Coupon Interest Payments and repayment of Face Value at maturity will be made free of any fees, charges, deductions or levies of the Australian Government, except to the extent required by law [with a separate section in the IM confirming the tax treatment, including the applicability of relevant withholding tax concessions/exemptions apply].

\subsubsection{NO ADDITIONAL AMOUNTS PAYABLE}

For the avoidance of doubt, in the event that any payment made by the Commonwealth in respect of Treasury Bonds is made subject to deduction or withholding for or on account of any Taxes, duties, assessments or governmental charges of any nature, no additional amounts shall be payable by the Commonwealth in respect of such deduction or withholding.

Source: https://www.aofm.gov.au/securities/treasury-bonds

\section{The procedural aspects of establishing General T\&Cs are also an important} issue to consider. A first important legal question is who approves the General T\&Cs on behalf of the State? Ideally, the public debt law will establish that the Minister of Finance's competency to do this. Before approving the General T\&Cs, it is good practice to retain specialized local counsel to advise the Ministry of Finance on the drafting and legal policy choices that arise in that context. However, in some jurisdictions (for instance, Ghana), their Constitution requires Parliament/Congress to approve such General T\&Cs, which could affect the timing of debt issuance and management operations. Finally, it is similarly good practice to consult with the local investor community, ideally in the context of an established market group. To the extent foreign investors are active, for instance as recognized primary dealers (PDs) (who are primarily considered to be intermediaries, participating in auctions, syndications etc. on behalf of investors), the former could also be included in the consultation. 


\section{B. The Form: Dematerialized Securities Holding Legislation}

\section{It is now generally accepted that the smooth settlement of bond transactions is best served by issuing and circulating those bonds in "dematerialized" form. ${ }^{30}$ Such} dematerialization can be achieved in two ways: (i) by "partial dematerialization, where securities that originally exist in materialized (i.e. bearer or registered) form are "immobilized"; 31 or (ii) by "full" dematerialization, where securities have no longer any material form. ${ }^{32}$ As a result of these processes, the securities will for all practical purposes exist only as dematerialized credit balances on securities accounts, held in the books of the CSD or properly licensed custodians. This allows in turn settlement of transactions in the local currency bond market by mere debits and credits of cash and securities accounts, ideally under a "delivery versus payment" mechanism. Such a form of settlement is efficient and safe. At the same time, such dematerialized securities will be held in an "intermediated manner," that is through a custodian, which gives rise to other risks that must be mitigated.

\section{Many countries lack a robust legal framework for dematerialized securities.}

Traditional securities law (including doctrines such as on negotiable instruments, Wertpapiere or valeurs mobilieres) ${ }^{33}$ recognizes three forms of securities: (i) bearer securities that are transferred by manual tradition; (2) registered or "nominative" securities that are transferred by registration in a registry; and (iii) "to order" securities that are transferred by endorsement. In many countries, these forms of securities do not fit very well into the legal framework for "irregular deposit," which is the general legal framework for the deposit and safekeeping of fungible (tangible) goods. As a result, questions arise as to core issues related to dematerialized securities, such as: what is the exact legal nature of the depositors claims vis-à-vis the depositary (right in rem or right in personam); what is the treatment of those claims in case of insolvency of the depositary; how can the holders of dematerialized securities exercise their contractual or company law rights vis-à-vis the issuer (e.g. voting in

\footnotetext{
${ }^{30}$ IMF/World Bank Group Guidance Note for Developing Government Local Currency Bond Markets (forthcoming).

${ }^{31}$ Materialized securities are effectively "immobilized" where the clearing system requires the issuer to issue a physical global bond document of title representing the entire issuance, which is held by the clearing system or a common depositary on its behalf.

32 The terms "materialized" and "dematerialized" are used here in sense described for the analytical purposes of the Working Paper, acknowledging that jurisdictions differ in how they allocate those qualities to a specific form of securities.

${ }^{33}$ This field of law started to develop in the $13^{\text {th }}$ century with the development of bills of exchange in northern Italy and came to full maturity in the $19^{\text {th }}$ century.
} 
a general assembly of shareholders); and which private international law rules will apply to dematerialized securities (lex rei sitae in principle only applies to tangibles)? ${ }^{34}$

40. Leading jurisdictions have sought to address this problem through the enactment of specific "securities holding legislation" for dematerialized securities. Often, this endeavor was undertaken in the context of the political decision to develop the jurisdiction as a safe haven for securities depositary activity. This can also be achieved through a phased approach. Specifically, in a first phase, countries have allowed the fungibility of bearer securities, and in a next phase enacted legislation allowing the creation and holding of fully dematerialized securities. The most famous example of the first phase was the Belgian Royal Decree Nr. 62, which allowed for the establishment of the Euroclear International Central Securities Depository as a response to the development of the Eurobond market in the 1960s. This Royal Decree subsequently influenced the Luxembourg legal instruments (the latest one being the Law of 1 August 2001 on the Circulation of Securities) that lay the legal foundation for the CEDEL International Central Securities Depository, later renamed into Clearstream, and even Art. 8 of the US Uniform Commercial Code. ${ }^{35}$ Another good example of a supporting legislative instrument is Regulation (EU) $N^{\circ}$ 909/2014 of 23 July 2014 on improving securities settlement in the EU and on CSDs, as it sets standards across the EU.

\section{Well-designed securities holding legislation will establish a comprehensive} framework for the issuance, holding and circulation of dematerialized securities. In most countries, there is a strong argument for establishing full dematerialization, at least for public debt and corporate securities listed on regulated markets. To achieve this, the law will need to: require that those securities be issued in the competent CSD; ${ }^{36}$ determine which types of financial institutions can act as direct participants in those CSDs; provide for clear mechanisms that protect depositors against the insolvency of their custodian; establish clear rules governing "corporate actions"; and modernize relevant private international law rules.

\section{Over the past decades, commendable steps have been taken to codify good practice in respect of securities holding legislation in a number of international legal instruments. The Geneva Securities Convention of UNIDROIT presents a robust and}

\footnotetext{
34 This question is discussed in detail in the Explanatory Report of the 2006 Hague Securities Convention (https://www.hcch.net/en/publications-and-studies/details4/?pid=2955\&dtid=3). See also, for instance, Kronke, H., The Draft Unidroit Convention on Intermediated Securities: Transactional Certainty and Market Stability, on www.imf.org, and Thevenoz, L., Intermediated Securities, Legal Risk, and the International Harmonisation of Commercial Law, Duke Law School Legal Studies Paper No. 170.

${ }^{35}$ See for instance the seminal paper of Guynn, R., Modernizing Securities Ownership, Transfer and Pledging Laws-A Discussion Paper on the Need for International Harmonization, International Bar Association, 1996.

${ }^{36}$ See Wendt, F., Katz, P., and Zanza, A., Organizing Central Securities Depositories in Developing Countries-Seven Considerations, IMF, WP/18/66.
} 
detailed framework for substantive rules on intermediated securities holding. ${ }^{37}$ This instrument is complemented by the Hague Securities Convention of the Hague Conference on Private International Law. ${ }^{38}$ This convention establishes a modern and comprehensive framework for private international law questions pertaining to dematerialized securities. Countries modernizing their securities holding law would be well advised to give due consideration to those legal instruments.

\section{From the IMF staff's experience (which is derived from IMF staff provision of} TA), designing an appropriate securities holding legal framework is not an easy endeavor. The main challenge is to develop rules that fit well into the broader legal framework of the country. Especially in countries of the civil law tradition, the Civil Code and commercial law will often include good building blocks that require conceptually relatively minor tweaks (for instance, to ensure that intangible bundles of rights incorporated in dematerialized securities can receive the treatment of tangibles under property and private international law). If, however, legal concepts are introduced from another legal tradition (for instance, trust or nominee structures from common law), such "transplants" could give rise to significant challenges further down the road.

\section{The introduction of a dematerialized securities holding regime causes risks that} must be mitigated through appropriate legal instruments. Specifically, the adoption of a legally robust private law framework must be complemented with an equally robust public law regulatory framework. That framework should first establish the exercise of custodial services to the public as a regulated activity, reserved to properly licensed financial institutions. In most countries, this activity should only be exercised by banks and brokers. Furthermore, the regulatory framework applicable to the securities holding activities of those financial institutions should require the latter: (a) to adopt a "fit for purpose" securities holding accounting framework; and (b) to segregate at the higher level (typically the CSD) their own holdings from the collective holdings of their clients. These are preconditions for ensuring that investors can recover their securities in case their custodian becomes insolvent. Custodians should also be prohibited from using the securities deposited by their clients, at least without their explicit consent. Finally, a strong supervisory framework to enforce these rules will be the "keystone" to building and maintaining investor confidence.

\footnotetext{
${ }^{37}$ UNIDROIT Convention on Substantive Rules for Intermediated Securities, at: https://www.unidroit.org/instruments/capital-markets/geneva-convention

${ }^{38}$ Convention of 5 July 2006 on the Law Applicable to Certain Rights in Respect of Securities held with an Intermediary, at: https://www.hcch.net/en/instruments/conventions/full-text/?cid=72
} 


\section{The Use: Secondary Market And Collateral Transactions}

\section{A. Outright Sales/Purchases}

\section{In most jurisdictions, the outright sale/purchase of bonds or bills in the} secondary market raises few legal issues. Such transactions will typically be governed by the applicable rules of civil or commercial law as well as the rules of the relevant securities settlement system (or CSD). When these transactions are settled "delivery versus payment" in the relevant securities settlement system (see below discussion in relation to settlement finality), the delivery of the purchased security and the payment of the price occur concomitantly, thus reducing legal and credit risks.

\section{B. Financial Collateral Law}

46. The use of LCBs as collateral is a central feature of the money, FX and interest rate derivatives markets, and hence a foundation of the broader LCBM. Local currency government bonds constitute the typical collateral in repurchase and derivative transactions under global (e.g. ISDA) or local standardized master agreements.

47. In many countries, the legal framework does not support the use of repurchase agreements and other flexible yet legally robust collateralization techniques. The main problems are the following: ${ }^{39}$

- $\quad$ Numerus Clausus Principle and Recharacterization Risk: Most legal systems follow the principle that the rights in rem that can be created by contractual parties are fixed (hence the numerus clausus) and cannot be expanded through contractual freedom. While nothing prevents contractual parties to be innovative as long as all goes well, insolvency courts developed the practice of "recharacterizing" nonrecognized rights in rem into such existing rights, and subsequently finding that some key requirements for their legal validity have not been complied with, thus resulting in their non-enforceability. This risk is particularly acute for the use of ownership rights as a collateral technique, which is the case of repurchase agreements and transfer of title arrangements used under derivative agreements.

- Claw Back Rules: Many jurisdictions include so-called "claw back" or avoidance rules, which allow insolvency practitioners or courts to take action to return payments and asset transfers made by an insolvent party prior to its insolvency. These rules typically consist of: (i) rules related to preferential payments made during a "suspect period" of often 6 months or a year; and (ii) fraudulent payments which can be

\footnotetext{
${ }^{39}$ Examples of other problems are: (i) old-fashioned pledge rules that require a court order for the enforcement sale of financial collateral: (ii) uncertainty about the rules governing cash collateral; and (iii) uncertainty as to the private international law principles that will govern the collateralization of dematerialized securities.
} 
undone often without time limit (the actio pauliana). These rules may hinder the use of substitution and margin calls. Substitution allows the collateral provider contractually to substitute one security with another during the duration of the collateral contract. Margin calls are a core tool in modern financial risk management and give the collateral taker the contractual right to request the delivery of additional securities if the overall value of the collateral portfolio has fallen (typically after a "marking to market") below a contractually stipulated threshold. In both cases, "isolated" deliveries of securities could be declared unenforceable if they occur during the suspect period preceding the insolvency of the collateral provider.

- $\quad$ Risks to Close-Out Netting: Traditionally, insolvency laws include the principle that set-off and netting are not enforceable against the insolvent estate following the occurrence of a defined 'insolvency event.' Furthermore, the opening of an insolvency procedure typically gives rise to a statutory moratorium on creditor action without the permission of the court. This will be problematic in the context of financial collateral agreements. These agreements typically include "close-out netting" provisions that allow one party, in case of default (as defined) by the other party, to close out, i.e., to terminate all outstanding transactions covered by the agreement, calculate the exposures under each transaction, net all mutual exposures, and satisfy the resulting net claim by enforcing the financial collateral. Nonenforceability of netting makes such provisions non-operative, resulting in the loss of a linchpin feature of capital markets risk management.

\section{To mitigate those legal risks, most countries need to adopt so-called "financial} collateral" legislation. Formally, this type of legislation is sometimes combined with settlement finality legislation (see below) and/or (amendments to) legislation that provides explicit legal recognition to derivative transactions in a single instrument. Substantively, this legislation seeks the following outcomes:

- Explicit recognition of the legal validity and enforceability of repurchase and other forms of transfer of title arrangements by way of security, thus removing recharacterization risk;

- $\quad$ Protection of collateral substitution and margin call during suspect periods (except for explicit fraud);

- Modernization of pledge rules, especially in view of cash collateral and dematerialized securities, for instance by allowing enforcement without court order (thus departing from the widespread prohibition of the pactum commisorium) and the transfer of ownership rights over pledged securities from pledgor to pledgee (recognition of the pignus irregulare);

- $\quad$ Protection of enforceability of close-out netting provisions upon insolvency; and 
- Modernization of private international law principles in respect of the collateralization of dematerialized securities.

49. This exercise is underpinned by a wide body of international standards and good practice. UNIDROIT has issued the abovementioned Geneva Securities Convention and "Close Out Netting Principles," 40 which provide excellent benchmarking for law reform efforts. The same is valid for the equally abovementioned The Hague Securities Convention. The EU Financial Collateral Directive is an example of good practice of the legal design of a modern financial collateral framework.

\section{Central Bank Monetary Policy Legal Framework}

50. The legal framework governing the central bank's monetary policy implementation is an important application of the financial collateral law. Its purpose is to regulate the manner in which the central bank enters into Lombard and other "open market" operations, and other financial transactions, with a view to influence monetary conditions, and thus pursue its price stability objective. The legal nature of this framework is in most countries dual: the general principles are established in the central bank law, whereas the detailed rules are laid down in a contractual type of legal instrument ("general terms and conditions"), although some countries instead have recourse to a regulatory instrument.

51. The degree to which the monetary policy legal framework will allow counterparties to collateralize LCBs with the central bank will have a major impact on the attractiveness of those bonds for banks - the typical central bank counterparty - in particular. It is well understood that, in most countries, this will not be a problem for government bonds, as these are the collateral of choice for most if not all central banks. For corporate bonds this is however different. The design of a risk management framework is certainly a holistic exercise that raises complex policy issues. In that respect, it is submitted that the acceptance, in principle, of local currency corporate bonds that meet a certain standard (e.g., a minimum rating) in terms of credit risk, combined with strong risk management measures catering for their particular nature (e.g. their lower liquidity), is not inherently irreconcilable with sound risk management, and thus deserves consideration. From a legal policy perspective, this pleads for legal frameworks that support the wide circulation and broad use of corporate bonds, including as financial collateral.

\section{Another important aspect of the monetary policy legal framework is the} repurchase agreement that is used by the central bank. Many central banks prefer to document their repurchase agreements with monetary policy counterparties through a bespoke, local law-governed master agreement, rather than by internationally accepted master agreements (e.g., the GMRA). Often, that local law master agreement will become de

\footnotetext{
${ }^{40}$ Principles on the Operation of Close-Out Netting provisions, at: https://www.unidroit.org/instruments/capitalmarkets/netting
} 
facto or de jure the local market standard, including for pure inter-bank transactions without central bank involvement. Thus, the effort made by the central bank to design a wellstructured and balanced master repurchase agreement will have broader developmental effects on the money and local currency bond markets. The same conclusion applies mutatis mutandis for securities lending agreements.

\section{Tax Treatment of Primary and Secondary Market Transactions}

\section{It is also critical that the legal framework for taxation is appropriate for the} development and efficient working of the LCBM. Tax laws should encourage investment and liquidity in bond markets by ensuring: the appropriate treatment of repo transactions; the development of both the primary and secondary market; and a clear and effective tax treatment for each key class of investor that conforms to international good practices, including for foreign investors. The tax treatment of investment in the LCBM is essential to establishing critical links between LCBMs and international FMIs. This section provides detailed guidance with respect to developing an appropriate legal framework for the taxation of LCBs comprising government debt securities, noting that some aspects could equally apply to a broader subset of securities transactions taking place within the domestic capital market (for instance, the guidance set out below adopts best practice principles that would also apply when adapting the tax law framework to secondary transactions over all debt and equity securities).

\section{Objectives of tax law reform of LCBMs}

54. When assessing whether the legal framework for taxation is appropriate, the key objective is to identify and remove tax impediments to the development and efficient working of the primary and secondary LCBMs. This typically requires the careful design and implementation of suitable and accommodative tax law reforms that focus on both: (i) the supply side of LCBs (dealing with the tax treatment of the LCBs themselves in both the primary and secondary markets); and (ii) the demand side of LCBs (dealing with the effective and efficient alignment of that tax treatment between key institutional investor groups, including mutual and investment funds, to encourage investment and liquidity in LCBMs). Box 5 below summarizes the objectives of both these supply side and demand side tax law reforms. 
Box 5. Objectives of Supply Side and Demand Side Tax Reforms

Supply side objectives:

- Facilitate investment and issuance decisions relating to LCBs (e.g. by enhancing the development and efficient working of the primary and secondary markets).

- Identify and remove tax biases against investing in LCBs (e.g. when compared to other investment products such as other bonds or bank deposits).

- Minimize inefficiencies and tax law distortions (e.g. financial transactions taxes, non-standard third-party (withholding) tax obligations etc.)
Demand side objectives:

- Attractive to investors (e.g. channel savings into investment).

- Must not put investors in a worse situation than if they had invested directly (e.g. when investing through mutual or investment funds) - and often concessionary for portfolio investors.

- Need to understand relative tax efficiencies between channels/investment options.

\section{Multi-step approach to achieving tax law reform of LCBMs}

55. Many countries have an inadequate tax law framework governing the treatment of LCBs, which results in material tax impediments to the development and efficient working of the primary and secondary LCBMs. Designing and implementing a set of law reforms to achieve an effective and efficient tax law framework governing LCBs typically requires a multi-step approach. This ideally involves undertaking a diagnostic review of the existing tax law framework of the country that is comprehensive (i.e. covering both substantive and administrative provisions) in order to: (a) identify existing impediments and gaps in that framework as it relates to LCBs, with specific regard to international good practices; and (b) develop law reform options to address those impediments and gaps. It is also important that the tax law framework provides certainty with respect to all key primary and secondary market transactions for all key investor classes. For example, on the supply side, this should include not only the tax treatment of the LCBs themselves in the hands of all key classes of domestic and foreign investor, but also the tax treatment of secondary market transactions over LCBs by each of those investors which will become critical for liquidity, hedging and market-making etc. Similarly, on the demand side, it is important to achieve an effective and efficient tax alignment of LCBs between key institutional investor groupsincluding mutual and investment funds - in order to also encourage investment and liquidity in LCBMs.

56. Countries should develop their own individual tax law reform plan in a systematic and coordinated way, so that it is appropriately integrated with their national capital market development plan. The legislative action to be taken will 
ultimately depend on each individual country's legal tradition and baseline tax law framework, including its underlying fiscal and tax policy settings.

\section{A. Supply side treatment—primary and secondary market}

\section{It is important to understand the scope of the tax treatment issues that should be} addressed by the tax law framework. As a first step, it should address each key investor class from a supply side perspective (dealing with the treatment of the LCBs themselves). Box 6 provides some high-level guidance in this regard.

\section{Box 6. Tax Treatment Issues to be Addressed by the Tax Law Framework Supply Side}

Taxation of LCBs themselves:

- Primary market:

- $\quad$ Address both local and foreign investors; and

- Treatment of returns (e.g. interest, discount etc.).

- Secondary market (important for hedging, liquidity etc.):

- Taxation of gains (e.g. on sale), including sale amounts attributable to accrued interest (often treated as interest if tax favored compared to trading/capital gains);

- Taxation of repos (see Box 8);

- Taxation of securities lending (similar considerations to repos);

- Treatment of financial collateral (similar considerations to repos); and

- Taxation of derivatives (increasing trend towards mark-to-market approaches).

\section{A key objective of well-designed supply side tax measures is to remove tax}

biases. This supply side objective focuses on dealing with the treatment of the LCBs themselves (the investment supply) and should have specific regard to the treatment vis-à-vis other investments (other investment supplies). The idea is to identify and remove tax biases which might make create a bias in favor of investing in other financial instruments and against LCBs. This step is more about achieving, at a minimum, tax neutrality. For example, having LCBs taxed at a higher rate when compared to other alternative financial instruments would create a bias against investing in LCBs. Another (common) example would be if a gain on the secondary sale of a LCB was subject to tax at the ordinary income tax rate (e.g. 30\%), rather than the reduced rate applicable to interest income (e.g. 15\%) in circumstances where that gain is solely attributable to accrued interest (for instance, which can arise, as discussed below, where the secondary sale occurs between two coupon payment dates). This would also negatively impact on secondary market activity and hence liquidity (so secondary market issues are also discussed below as part of the supply side tax treatment issues in this Working Paper). 
59. When designing the necessary supply side tax law reforms, consideration also needs to be given to the legal modalities relating to the issuance and trading of LCBs and associated FMIs, given an integrated tax law framework requires consistency with the country's overarching legal infrastructure. As discussed above, for example, in the context of facilitating foreign investment, interest withholding tax and capital gains/profits tax concessions/exemptions in relation to returns and gains on LCBs that are consistent with international common practice often become necessary to achieve critical investment links between LCBMs and international FMIs. In this regard, more generous tax treatment often applies for non-residents investing in LCBs (otherwise FMIs will remain unprepared to establish a link with many small and underdeveloped capital markets). However, the ultimate tax treatment of a country's LCBs is a matter of domestic tax policy, having regard to their capital markets development plan. ${ }^{41}$ The position with respect to local investors is more complex (and those investors ideally should be taxed on the grounds on equity and fairness between domestic taxpayers, subject to any constitutional constraints with respect to treating non-residents more generously), but relief for foreign investors on LCBs (and, where appropriate, other publicly issued securities) is common international practice for a number of reasons (see also section VI above). For present purposes, a baseline tax treatment reflecting common international practice with respect to the treatment of LCBs comprising government debt securities is set out in (Table 2) below.

\begin{tabular}{|c|c|c|}
\hline \multicolumn{3}{|c|}{$\begin{array}{l}\text { Table 2. Baseline Tax Law Treatment of LCBs comprising Government Debt } \\
\text { Securities for Local and Foreign Investors }\end{array}$} \\
\hline Investors & Gains & Interest \\
\hline Residents & Tax* & Tax* \\
\hline Non-residents & $\begin{array}{c}\text { Exempt** } \\
\text { (no withholding tax) }\end{array}$ & $\begin{array}{c}\text { Exempt** } \\
\text { (no withholding tax) }\end{array}$ \\
\hline
\end{tabular}

* Subject to domestic tax policy positions and capital markets development plan.

** This tax treatment is sometimes extended to other publicly issued debt securities (a discussion of which is beyond the scope of this Working Paper), but when doing so the qualifying conditions should be carefully circumscribed, particularly with respect to interest payments to non-residents to safeguard against abuse.

60. If seeking to tax investors on either their LCB gains or returns, it is important that the tax treatment is clear and unambiguous under the tax law. Navigating this tax law design complexity to achieve clear and unambiguous tax treatment often becomes difficult and reflects why an established international practice has emerged of not seeking to tax foreign investors on their LCB gains, together with providing appropriate interest

\footnotetext{
${ }^{41}$ Countries remain free to tax gains or returns on all securities whether they are held by local or foreign investors, subject to applicable tax treaties.
} 
withholding tax concessions in respect of coupon payments made to foreign holders, given both positions also represent the approach preferred by FMIs (as discussed above). To give a sense of the tax law design complexity when seeking to tax foreign investors on their LCB gains (even putting aside the more complex collection and enforcement difficulties), certainty would be required with respect to the following: (i) whether the gain is characterized as a revenue gain or capital gain, which is a relevant distinction made by many domestic tax systems (as a different tax treatment or tax rate can apply); (ii) the tax timing of the gain (which can differ depending on the structure of the LCB itself and how the gain is realized); and (iii) whether the gain has a local source (as foreign investors are typically only taxable on locally sourced gains under established international tax norms). Greater certainty is achieved when all these aspects are prescribed by the tax legislation (which should be the preferred approach), rather than, for example, the courts (for instance, in the absence of having a statutory definition of "source", many common law countries have left the courts to develop the principles for determining the "source" of gains, which can be particularly problematic when outdated common law source rules are applied to fast moving and innovative capital market transactions). In the absence of clear tax rules (and often the best designed tax laws are still not perfect), it can become difficult for a foreign investor in a LCB with no other presence in the country that issued the LCB to determine their tax treatment with the certainty required to support their investment demand. The complications multiply when a local or foreign intermediary is used by foreign investors to manage assets or settle transactions (which is also typically the case) because their use can, in turn, in the absence of clear tax rules give rise to a taxable presence for the foreign investor in the country of the intermediary (and also a local source for the resulting gain where a local intermediary is used which can expose it to unintended tax consequences). The complexity can be more easily resolved where a tax treaty allocates taxing rights and source. However, where no tax treaty is applicable, the position remains complex and has led to the practice of not seeking to tax foreign investors on their LCB gains. ${ }^{42}$

\section{In terms of the tax treatment of LCB returns, "interest" should ideally be}

defined broadly in the tax law. This reflects the fact that there is considerable flexibility on international monetary markets as to how financial instruments may be structured. The definition should capture not only ordinary notions of "interest" (e.g. coupons on LCBs) but also certain amounts attributable to, or functionally equivalent to, interest. Clearly defining these amounts can also be important for the imposition or non-imposition of non-resident withholding tax, as well as providing certainty in relation to the tax treatment of secondary sales of debt securities. Examples of amounts that are functionally equivalent to interest include an amount payable for the time value of money under a derivative financial instrument (such as a swap) and a payment of defaulted interest by a guarantor. Additionally, several countries are seeking to develop their domestic Sukuk markets to tap Islamic

\footnotetext{
${ }^{42}$ Even when conforming to international practice of not seeking to tax foreign investors on their LCB gains, there is still often a need to support this practice by enacting legislative confirmation that the exemption will be preserved even if a local intermediary is used.
} 
financial markets by issuing a variety of Sukuk structures and maturities ${ }^{43}$ making them potentially promising for LCBM development. ${ }^{44}$ As a general rule, the tax treatment of income from Islamic financial transactions should also be aligned with that of conventional financial transactions that they are economically equivalent to. Capturing amounts that are functionally equivalent to interest in nearly all cases will achieve better neutrality of tax treatment between similar financial instruments.

62. Further, when a debt security is sold between interest payment dates, part of the sales price will typically represent interest accrued to the date of the sale. A common issue is that the tax law does not differentiate between gains on the sale of debt securities (which can be subject to profits tax, particularly for resident investors) and that part of the sales price which is attributable to accrued interest (which could be treated as interest). If not appropriately aligned, anecdotal evidence in a number of countries suggests that parties to a secondary sale of debt securities could seek to settle the transaction on interest payment dates, or otherwise attempt to apportion coupon amounts between those parties in order to avoid adverse or uncertain tax outcomes (e.g. higher tax rates on capital gains when compared to interest income which may be accrued in the capital gain). This leads to complexity and inefficiency in ordinary market transactions.

\section{It is common international practice in major financial centers to treat as interest} that part of the sales price that represents interest accrued to the date of the sale. Under this treatment, the seller would report part of the sales price as interest income, and the buyer would treat the interest amount subsequently received as a return of capital investment, reducing their tax basis in the relevant debt securities.

\section{Further, a deep and more mature capital market will offer a suite of more complex bond offerings and secondary market transactions relating to LCBs. These} transactions also eventually become an integral part of the capital market and financial system. Therefore, it is important that the tax law framework provide clear, internationally comparable, rules for determining the tax treatment of all other returns from LCBs (e.g. discounts, premiums and other maturity amounts). Similarly, the tax law framework should also provide clear, internationally comparable, rules for determining the tax treatment of the typical secondary market transactions over LCBs that will be entered into by each key class of domestic and foreign investor (such as the tax treatment of gains on secondary sale for both retail and institutional investors, as well as repurchase transaction, securities lending,

\footnotetext{
${ }^{43}$ A sukuk is structure under which a financial certificate is issued on terms requiring periodic amounts to be paid, and such payments are supported by a regular stream of receipts from underlying assets, debts, projects, investments or businesses. It is the Islamic equivalent of a debt security, but unlike a conventional debt security, which represents the debt obligation of the issuer, the periodic amounts paid under a sukuk are technically proportionate share of returns generated by the underlying asset, debt, project, investment or business (and a return of capital at a later date).
}

${ }^{44}$ Staff Note for the G20 IFAWG: Development of Local Currency Bond Markets: Overview of Recent Developments and Key Themes (Seoul, Korea, June 20, 2016). 
financial collateral, and derivative transactions for institutional investors) which is critical for liquidity, hedging and market-making.

65. The tax law framework should also embody appropriate rules-based integrity provisions to combat tax structures and transactions considered abusive or otherwise producing inappropriate policy outcomes These are often necessary to combat: (i) bond washing which consists of selling a bond just before it pays a coupon and then buying it back once the coupon has been paid to realize a tax-free capital gain or avoid withholding tax on the coupon; and (ii) an inappropriate deferral of tax under deeply discounted securities by taxing them on an accruals basis. Further, various secondary market transactions (such as repos and securities lending - discussed below) may give rise to unacceptable tax avoidance opportunities in different ways, which can also arise from specific interactions or gaps between tax rules. Sometimes these opportunities are closed by simply forbidding these transactions for certain types of taxpayers (for example, for $\mathrm{N}$-accounts in the Belgian $\mathrm{X} / \mathrm{N}$ clearing and settlement system). In other cases, they require specific legislative rules to combat them (for example, eliminating any potential double dip of tax credits through manufactured dividends).

66. It is also typical for an advisory, placement and asset management industry to develop in relation to $\mathrm{LCBs}$, and, over time, LCBs with more complex design features will develop and other securities, financial products and instruments will also become available in the financial market. Putting in place a more comprehensive tax law framework as it relates to financial markets upfront will ensure that the framework is equipped to deal with more sophisticated transactions and provide certainty to investors, once those markets deepen in the relevant emerging market and developing economy. For example, indexed bonds often develop after more vanilla LCBs, so the tax law framework should consider the likely evolution in LCB design features upfront to ensure certainty of tax treatment with respect to both tax characterization (e.g. confirming whether the indexed component of the return is to be treated as interest income rather than capital gain) and tax timing (e.g. whether or not accruals taxation could apply-particularly where the LCBs are also capital-indexed). In each case, complexity or uncertainty of tax treatment can materially and adversely impact investor appetite. Further, more complex and highly structured bonds can potentially transform a legal form debt instrument into one that, in substance, more closely resembles equity (e.g. use of convertible features adopted for solvency reasons). Many domestic tax systems have developed rules to determine whether the instrument issued constitutes debt or equity for tax purposes to provide greater certainty and appropriateness of tax treatment, although these rules are typically more relevant for non-government issued debt.

67. As noted above, often the existing tax law framework is capable of dealing with more vanilla transactions such as the issuance, buying and selling of LCBs, but does not contain any provisions to provide certainty in relation to the tax treatment of more 
complex issuances or secondary market transactions. The following discussion will focus on ensuring an adequate tax law framework for the following secondary market transactions:

- Derivatives;

- $\quad$ Securities lending; and

- Repos.

\section{Derivatives}

68. Derivative markets are an integral part of the LCBMs. Derivatives also play an increasingly important role in modern financial markets. Derivatives typically include forward contracts, futures, swaps, and options and combinations of these. A derivative contract is an agreement between two counterparties (i.e. a buyer and a seller), which specifies how the value of the contract evolves over time (e.g., by reference to an underlying object). As noted above, a derivative is commonly documented using an industry standard master agreement published by the International Swaps and Derivatives Association Inc., (ISDA) (ISDA Master Agreement) and Schedule, and an ISDA Credit Support Annex or similar document (CSA). The ISDA Master Agreement, Schedule and CSA are collectively referred to as the ISDA.

69. Under the ISDA (and depending on the nature and terms of the underlying derivative arrangement), certain periodic and final balancing payments will typically become payable between the counterparties. Under the ISDA's CSA, or similar arrangement, one counterparty (e.g. buyer, or vice versa) will typically be required to provide cash or securities to the other counterparty (e.g. seller, or vice versa) as financial collateral in respect of any mark-to-market (MTM) exposure against the relevant counterparty under the derivative.

70. Many emerging markets and developing economies jurisdictions operate under a choice of law principle for derivatives, such that local counterparties are free to enter into an ISDA that is governed by foreign law, particularly where the ISDA is being entered into with a foreign counterparty. Parties could, for instance, enter into a standard collateral document governed by New York law (NY Law CSA) or one prepared for use under English law (English Law CSA). From a tax law perspective, the choice of foreign law itself is generally not that material. However, to the extent that the use of a document governed by foreign law affects the legal characterization of a relevant transaction under the relevant ISDA agreement, the tax law framework would need to address this. For example, on the financial collateral side, English Law CSAs typically give rise to an absolute transfer of title of the collateral, whereas NY Law CSAs generally give rise to security interests only (similar to pledge). The domestic tax law will need specific rules to accommodate both of these possibilities to achieve neutrality between them. Where there is an absolute transfer of title of financial collateral, then the arrangement typically operates in a similar way to securities lending transaction and therefore those rules (discussed further below) also become 
important to support derivative transactions (by, amongst other things, disregarding both the transfer and return of the financial collateral for the collateral giver). Alternatively, where the transfer of the financial collateral gives rise to a mere security interest only, then it is common for the tax law to already not treat the transfer as a disposal (which is similar to the existing tax treatment for a home owner when taking out a mortgage on their home, which does not result in a disposal of that property to the bank mortgagee for tax purposes, even if title to the property were to be transferred to the bank under that mortgage for security registration purposes).

71. There is a trend internationally to treat the derivative transaction itself (as distinct from the financial collateral supporting it) for tax purposes in the same way as they are treated for financial accounting purposes in accordance with IFRS. This is particularly so for financial institutions who are the typical counterparties that enter into initial secondary market transactions over LCBs. Under a tax law model that aligns the tax treatment of derivatives with their accounting treatment, positive movements in the value of a derivative contract (i.e. fair value or MTM movements) would be subject to tax consequence each year, even if the gain and loss are unrealized. There is a trend towards this treatment in a number of financial centers (see, for example, recent derivatives reforms in the U.K., and proposed reforms in the U.S. etc.).

72. Jurisdictions that have adopted this model for derivative transactions will often consider whether to also adopt some (elective) exceptions to MTM taxation to smooth out the impact on certain hedges etc. Under hedging strategies, financial institutions will often try to reduce or mitigate the financial effects from risks that could impact upon the institution's business. The company will often enter into derivative contracts which will be structured to minimize these risks. The hedged item is the asset, liability or future transaction whose risk is being mitigated. The broad effect of these exceptions is to disregard the fair value or MTM movements on the derivative and instead to bring profits and losses into account for corporate income tax purposes in line with the hedged item.

73. In the absence of MTM taxation or where that treatment does not otherwise apply (e.g. because it only applies to financial institutions), then the derivative transaction is typically taxed on a realization basis. This would mean that gains or losses arising from those derivation transactions are ordinarily brought to account for tax purposes when the respective periodic and final balancing payments are payable/made between the counterparties (e.g. at relevant settlement times). Given the flexibility within which derivatives can often be settled and the possible arbitrariness of tax consequences that could follow, authorities should be vigilant for signs of abuse when a realization basis applies for tax purposes. 


\section{Securities lending arrangements and financial collateral}

\section{Securities lending transactions are essential to the liquidity of the capital}

markets and to facilitate the provision of hedging strategies to investors. While similar to a repo in some respects, there are important legal and tax law differences.

\section{The essential features of a securities lending agreement (SLA) are:}

- The "lender" agrees to transfer securities to the "borrower" in return for the promise of the "borrower" to return unascertained identical (i.e. equivalent but not the very same) securities, either on a fixed future day or, more commonly, on demand (but with a maximum term of say less than 12 months). Transactions are typically affected under the standard form Global Master Securities Lending Agreement (GMSLA). In respect of financial collateral arrangements under derivatives, the transaction could be affected under an industry standard CSA, so these rules become important to also support derivative transactions (as noted above).

- $\quad$ As in the case of a repo, all transfers of securities pass absolute title to those securities to the transferee. There is thus no "loan" of securities. These features are the same as a mutuum under Roman law. ${ }^{45}$

- Invariably, the "borrower" must, directly or indirectly, provide the "lender" with a fee, which is usually calculated or earned in a manner similar to interest.

- In theory, a securities lending transaction can be unsecured. However, in practice this is rarely (if ever) the case between arm's length parties. The security can be provided, broadly, in one of three ways:

$>\quad$ By the borrower providing an irrevocable standby letter of credit or guarantee from a creditworthy institution;

$>\quad$ By the borrower furnishing cash collateral;

$>\quad$ By the borrower providing non-cash collateral (e.g. equities or debt securities such as LCBs) under what is effectively a parallel securities loan, under the same SLA, (in that absolute title to the collateral securities passes to the "lender", who is obliged to deliver identical (but not the very same) ones on the return of identical original securities by the "borrower").

- If a record date for the payment of a dividend, coupon or other distribution occurs during the period of the securities borrowing, the borrower must typically make a

\footnotetext{
${ }^{45}$ A mutuum was a loan for consumption of certain types of fungible consumables obliging the borrower not to return the thing itself (because it would be used up in consumption), but a similar thing in quality, quantity and size.
} 
manufactured payment to the lender of the relevant securities equal to the amount of the relevant distribution.

\section{In the absence of specific tax law provisions, the following tax consequences generally then arise:}

- The lender is treated as having disposed of the securities that were lent at the time the securities lending arrangement was entered into; and

- That disposal could result in a taxable gain or loss for the lender in respect of the securities that were lent under the securities lending arrangement, based on the market value of the relevant lent securities at the time the original securities lending transaction was entered into.

\section{Many jurisdictions that tax capital gains on transfer of securities implement} specific provisions relating to securities lending arrangements. Those specific provisions applying to a securities lending arrangement can operate as follows:

- $\quad$ The lender is essentially treated for tax purposes as though it has never disposed of the securities when they are lent under the arrangement, but the lender is taxable on the fee income earned.

- $\quad$ Any gains or losses that would otherwise be realized by the lender on the transfer of securities to the borrower and the later acquisition of equivalent securities under a securities lending arrangement are ignored.

- The return of equivalent securities does not of itself result in any gain or loss to the borrower. However, the borrower would make an overall profit or loss from the arrangement to the extent that the value of the equivalent securities returned to the lender is less that the value of the borrowed securities sold by the borrower.

- The borrower would include in their gross income the receipt of any dividend, coupon or other distribution but should deduct the manufactured payment payable to the lender, thus leaving the borrower in a tax neutral position.

- $\quad$ The manufactured payment will be included in gross income of the lender, but that payment can be treated as if it were a dividend or interest on the securities (as the case may require). 


\section{A sample set of legislative provisions are set out in Box 7 below:}

\section{Box 7. Sample Legislative Provisions: Securities Lending Arrangements}

\section{Securities lending arrangements}

(1) Subsection (2) applies when a securities lending arrangement is entered into that satisfies the following conditions:

(a) the arrangement has been entered into in writing using industry standard documents;

(b) the security (or an equivalent security) is returned within twelve months after it is lent;

(c) the parties deal at arm's length in relation to the transaction; and

(d) if a record date for the payment of a dividend, coupon or other distribution occurs during the period of the arrangement, the borrower is required to must make a manufactured or equivalent payment to the lender of the relevant securities equal to the amount of the relevant distribution.

(2) Where this subsection applies, the arrangement is to be treated as follows:

(a) both the delivery of the securities and the return of securities or equivalent securities by the borrower are ignored for the lender;

(b) this Act applies to the lender as if the manufactured or equivalent payment under the arrangement were a dividend or interest on the securities (as the case may require);

(c) the tax cost of the borrowed securities for the borrower and the consideration for the return of the securities or equivalent securities to the lender is to be treated as being equal to the market value of the securities at the time that they were borrowed by the borrower from the lender; and

(d) The borrower must include any gain related to the arrangement in gross income and may deduct any loss related to the arrangement from gross income in accordance with the Act.

\section{Repo transactions}

79. Repurchase agreements (repos) have long been common in both the domestic and international bond markets and are essential in maintaining liquidity in those markets. Typically, such transactions have been affected under a Global Master Repurchase Agreement including associated schedules and annexes (the GMRA). However, as discussed above, repo transactions with a central bank are sometimes also affected under a bespoke 
local law governed master agreement, which may become - the de facto or de jure-local market standard. ${ }^{46}$

\section{A repo has the following essential features:}

- $\quad$ One party (Seller) agrees to sell unascertained securities to the other (Buyer) for a fixed cash price (equal to approximately the current market value of the securities or between $100 \%$ and $105 \%$ thereof), with settlement taking place almost immediately. This is effectively a spot sale of the securities.

- Simultaneously, under a related transaction, the Buyer agrees to sell to the Seller unascertained identical (i.e. equivalent but not the very same) securities, either on a fixed future date or on demand, for cash. This is effectively a forward sale agreement in respect of unascertained equivalent (i.e. unidentifiable or non-specific) securities. The purchase price under the forward agreement is a function of the purchase price under the spot sale. If, say, the market rate of interest for a cash deposit in the relevant currency (say USD) was $6 \%$ pa, then the re-purchase price is calculated as initial purchase price under the spot sale, times $106 \%$, times number of days between the date of completion of the spot sale and the date of completion of the re-purchase agreement, divided by 365 (or sometimes 360). In other words, the Buyer effectively gets back their initial purchase price under the spot sale plus an amount calculated in the same manner as, and equivalent in substance to, interest.

- All transfers of securities pass absolute title to those securities to the transferee.

- If the repurchase agreement straddles a record date for the payment of interest or another kind of distribution on the security, then, on the income payment date, the Buyer must pay an equal amount to the Seller. However, under a variation to the arrangement, instead the repurchase price is reduced by approximately the same amount. Such a variation is called a "buy/sell" transaction, rather than a "repo".

- $\quad$ The principal difference between a repo and a securities lending transaction relates to the character of any cash which passes from the borrower to the lender at the time when the securities are "lent":

Under a securities lending transaction, the cash collateral is in the nature of a security deposit, to facilitate the exercise by the lender of a right of set-off, or netting, on default by the borrower.

\footnotetext{
${ }^{46}$ In Europe, there is also the European Master Agreement of the European Banking Federation.
} 
Under a repo, the cash is in the nature of a purchase price. The initial Seller does not have to be able to set-off or net in order to retain the cash, in the event of the initial Buyer's default and insolvency.

81. Like the case with respect to securities lending transactions (discussed above), a tax law framework for repo transactions could be distortionary if it is structured based on the legal structure of the repo (sale and repurchase) rather than its economic substance (collateralized borrowing). It is desirable to treat income and gains from, and the costs of, repo transactions as interest income and expenses respectively, rather than as giving rise to capital gains and losses, and also to ensure transaction amounts are free from withholding tax. Transaction taxes on repos (or securities lending transactions) are also not helpful in developing capital markets. Box 8 summarizes the key tax considerations relating to repo transactions.

\section{Box 8. Key Tax Treatment Considerations for Repos}

- Ensure both the transfer and return of the securities is disregarded for the seller to avoid taxable gains/losses from otherwise being realized by the seller.

- Treat as interest (or equivalent) the amount by which the agreed repurchase price exceeds the amount of the initial sale to better align the tax treatment with the substance of the repo transaction.

- Ensure taxation of third party (e.g. rehypothecation or reuse) transactions for the buyer.

- Clarify the tax law treatment of manufactured payments, which could be treated as equivalent to the receipt and payment of interest on the securities.

- Transaction taxes on repos (or securities lending transactions) are also not helpful in developing capital markets.

82. A sample set of legislative provisions are set out in Box 9 below (which largely replicate those relating to a securities lending transaction, but as modified to reflect the different characteristics of a repo): 


\section{Box 9. Sample Legislative Provisions: Repo Arrangements}

\section{Repo arrangements}

(1) Subsection (2) applies when a repurchase (repo) arrangement is entered into that satisfies the following conditions:

(a) the arrangement has been entered into in writing using industry standard documents;

(b) the security (or an equivalent security) is repurchased within twelve months after it is transferred;

(c) the parties deal at arm's length in relation to the transaction;

(d) if a record date for the payment of a dividend, coupon or other distribution occurs during the period of the arrangement, the transferee is required to must make a manufactured payment to the transferor of the relevant securities equal to the amount of the relevant distribution.

(2) Where this subsection applies, the arrangement is to be treated as follows:

(a) both the sale of the securities and the repurchase of securities or equivalent securities from the transferee are ignored for the transferor;

(b) this Act applies to the transferor as if the manufactured payment under the arrangement were a dividend or interest on the securities (as the case may require);

(c) the tax cost of the acquired securities for the transferee and the repurchase price for the securities or equivalent securities by the transferor is to be treated as being equal to the market value of the securities at the time that they were initially sold by the transferor to the transferee;

(d) the amount by which the agreed repurchase price exceeds amount received on the initial sale of the securities is to be treated as a deductible finance charge to the transferor and is to be included in the gross income of the transferee; and

(e) the transferee must include any other gain related to the arrangement in gross income and may deduct any loss related to the arrangement from gross income in accordance with the Act.

\section{B. Demand side treatment}

83. On the demand side, it is important to achieve an effective and efficient tax treatment alignment of LCBs between key institutional investor groups-including mutual and investment funds - in order to also encourage investment and liquidity in

LCBMs. As distinct from simply identifying and removing tax biases (which was discussed 
as a supply side objective), the demand side objective is more about making financial investments, including in LCBs, more attractive to investors. In this regard, the demand side objective of being "attractive to investors" is about facilitating demand side investors (i.e. investor base) and understanding the effective tax treatment of utilizing various investment channels (e.g. investment by or though institutional investors such as investment funds or pension funds).

\section{It is beyond the scope of this Working Paper to provide a detailed discussion of the tax law design of regimes to cater for each demand side investor (i.e. investor base).} This requires a comprehensive understanding of the effective tax treatment of utilizing various alternative investment channels, the domestic tax policy settings of the individual emerging market or developing economy concerned, and their own specific capital markets development plan. For example, when developing a tax law regime for pension funds, it is first important to understand the existing tax treatment of long-term savings made through a pension fund, given that pension fund investors are often key demand side investors in capital markets and particularly in LCBs. ${ }^{47}$

85. An understanding of the scope of the tax treatment issues that should be addressed by the tax law framework for each key investor class from a demand side perspective is very important. Box 10 provides some initial key baseline insights relating to the tax law settings for those key institutional investors from that perspective.

\footnotetext{
${ }^{47} \mathrm{~A}$ common pension fund tax system is an Exempt/Exempt/Taxed (EET) system, namely: (i) contributions are not taxed (deductible to the payer and employer contributions are not taxed to employees); (ii) pension fund income is exempt; and (iii) pension fund pay-outs are taxed (both pensions and lump sums). This system typically operates as a deferral system with the tax on contributions and pension fund income deferred until pay-out. The advantage of an EET system is that savings can grow at a faster rate when compared to normal bank savings (which typically operate under a Taxed/Taxed/Exempt (TTE) system with: deposits made out of taxed income; interest income taxed; and withdrawals untaxed). Alternative pension fund tax systems will have different effects on the tax treatment of investing through a pension fund and must be analyzed to understand the likely impact on investment behavior. Designing a tax regime for pension funds (or any other institutional investor for that matter) demonstrates how understanding the tax treatment of long-term savings made through those investors (e.g. EET systems) becomes important to the whole tax landscape relating to LCBMs. What can be initially gleaned is that an EET system (commonly adopted for pension funds) operates as a deferral tax system when compared to the ordinary tax treatment of an investment in normal bank savings etc., with the possible effect of incentivizing (make more attractive) investment in LCBs or other financial instruments through pension funds, absent other specific incentive measures.
} 


\section{Box 10. Tax Treatment Issues to be Addressed by the Tax Law Framework Demand Side}

Investors to cover include:

- Investment and mutual funds: tax rules need to be attractive and neutral to investors (channel savings into investment; not put investors in a worse situation than if they had invested directly); but also need to consider treatment of investment management activity to encourage local management of funds.

- Pension funds: Exempt/Exempt/Taxed (EET) system or otherwise. In addition to national pension schemes, an understanding of all significant internal/private firm schemes and their applicable tax treatment should also be obtained to address any similar market inefficiencies.

- Insurance companies (life and general): assess relative tax treatment/neutrality of long-term savings made through a life insurance policy when compared to other investment options.

- Other investors, including local (e.g. financial institutions) and foreign investors (e.g. SOEs, family offices etc.).

\section{The Post Trading: Settlement Finality LaW}

86. Sound LCBMs require robust and sound post-trading infrastructure. ${ }^{48}$ This ensures that capital markets trades are effectively and efficiently settled. Post-trading infrastructure relevant to LCBMs consists mainly of: (a) the central bank's real time gross settlement system, which settles the cash leg of bond transactions; and (b) the securities settlement system of the central securities depository, which settles the securities leg. Ideally, bond trades are settled "delivery versus payment" 49 to reduce credit risk. In mature markets, clearing houses and central counterparties (CCPs) also play an important role by centralizing bond transactions with a view to reducing the total amount of transactions requiring settlement. The cash and securities transfers are typically settled on a gross basis, while presettlement clearing through a CCP takes place on a net basis, through netting.

\section{In many countries, post-trading infrastructures are subject to significant legal}

risks. These risks stem mainly from insolvency law and are three-fold.

\footnotetext{
${ }^{48} \mathrm{IMF} /$ World Bank Group Guidance Note for Developing Government Local Currency Bond Markets (forthcoming)

${ }^{49}$ Delivery-versus-payment systems provide a mechanism to ensure that the final transfer of one asset (for example, a security) occurs if and only if final payment also occurs.
} 
- Zero-Hour Rule: In many jurisdictions, the insolvency law includes a so-called "zero-hour" rule, which invalidates all payments and asset transfers made by an entity after $0.00 \mathrm{~h}$. on the day in which that entity was declared insolvent.

- Claw-Back Rules: The "claw back" rules discussed above could lead to the invalidation of certain payments and securities transfers executed in financial market infrastructures before the opening of insolvency procedures.

- Non-Enforceability of Netting: The abovementioned non-enforceability of netting could also cause the non-enforceability of the clearing, payment and settlement of bond transactions executed on a net basis.

\section{Each of these three legal mechanisms can invalidate cash payments and} securities transfers that were executed to settle LCB trades. Imagine a bank that is declared insolvent at $15.00 \mathrm{~h}$. and has made several payments and securities transfers since the payment and securities settlement systems opened at $9.00 \mathrm{~h}$. In accordance with the application of the "zero-hour" rule, the claw-back rules, or the non-enforceability of netting all or some of those payments and securities transfers could be invalidated and could lead to a return of the payments or transfers to the insolvent estate. This would result in spillover and ripple effects with affected counterparties.

89. To mitigate those legal risks and put the post-trading infrastructure on a sound legal footing, most countries will need to adopt so-called "settlement finality" laws to override above-mentioned legal mechanisms to systemically important post-trading infrastructures. ${ }^{50}$ The need for these laws is recognized by international standards. ${ }^{51}$ The main purpose of this settlement finality legislation (SFL) is to ensure that all payments and securities transfers effected up to the (notification of the) opening of insolvency are definitive, that is "final". The core components of a typical settlement finality law are summarized in Box 11.

\footnotetext{
${ }^{50}$ A very influential piece of settlement finality legislation was the EU's Settlement Finality Directive. Emerging and developing countries that have enacted similar legislation are Albania, Armenia, Georgia, Lesotho, Rwanda and the Ukraine.

${ }^{51}$ PFMI Principles, Principle 1.
} 


\section{Box 11. Settlement Finality Legislation}

- $\quad$ Personal scope of application: The SFL will need to carefully define its personal scope of application. Many countries only provide finality protection to payment and settlement systems that are operated or overseen by the central bank. In addition, most SFL only apply to payments and securities transfers made by banks and securities firms, and not to those of other financial institutions, such as insurance firms. Obviously, this question is linked to the choice as to which types of financial institutions are granted direct access to the post-trading infrastructure.

- $\quad$ Timing and information mechanisms: Most SFLs protect all payments, clearing and settlements effected before the operator of the payment, clearing or settlement system was formally notified of the insolvency of a participant. This requires that the insolvency court formally notifies the said operator of the insolvency of a participant.

- Override of "zero-hour" rule: To the extent insolvency law includes a "zero-hour" rule, that rule is overridden in respect of covered financial institutions and recognized posttrading infrastructures.

- $\quad$ Validity and enforceability of netting: The SFL declares netting and set-off between covered financial institutions in recognized post-trading infrastructures.

- Override of "claw-back" rules: Those rules are overridden in respect of covered financial institutions and recognized post-trading infrastructures. (But some SFLs allow for those rules to be enforced outside post-trading infrastructures.)

90. IMF staff provides TA on the design of settlement finality legislation, but this is not without challenges. Settlement finality legislation is complex. The design requires an understanding of insolvency law and similar mechanisms that can cause concursus creditorum. This has been a specific area of focused discussions between IMF staff and the authorities of IMF member countries in order to ensure that the complex interplay of legal mechanisms is understood. IMF staff has also sought to strengthen capacity building efforts in this area by providing training on these mechanisms, often in a regional context.

\section{Fiscal Agency Agreement}

\section{Fiscal Agency Agreements play a very important yet underestimated role in} supporting sound LCBMs. ${ }^{52}$ These agreements establish the roles and responsibilities of the

\footnotetext{
${ }^{52}$ See also Addo Awadzi, E., o.c., paras. 94-98.
} 
central bank as "banker to the State." 53 This function includes a role as depositary for the State's financial assets (cash and securities), the making of payments on behalf of the State, and often also a role in the issuance and management of public debt instruments. ${ }^{54}$

92. While the key features of the fiscal agent role are typically established in the central bank law and sometimes also in public debt legislation, it is in most countries necessary to further specify that role in some form of agreement. The content of the Fiscal Agency Agreement will hence be shaped by the contours of the central bank and public debt laws. ${ }^{55}$ From a formal perspective, this agreement can take the form of a formal contract, but in some countries it is established by exchange of letters between the Ministry of Finance and the central bank. From a substantive perspective, it is accepted that this agreement between two public bodies is governed by a mix of contractual and administrative law principles. In other words, it will seldom be considered as pure private law contract.

93. The rules governing the operation of the State's cash "current accounts" in the books of the central bank, and the Treasury Single Account in particular, are a core component of each Fiscal Agency Agreement. Specifically, the Agreement will stipulate which accounts are held, how those accounts are debited and credited, whether credit balances are remunerated, etc. Ideally, the Fiscal Agency Agreement will also stipulate how payments on coupons and maturing principal of local currency government bonds are to be affected.

94. In countries where the central bank plays an important role in respect of the issuance and management of local currency government bonds, the Fiscal Agency Agreement will need to provide for a clear delineation of roles and responsibilities between the State and the central bank. For instance, whereas the central bank might be charged with organizing the auctions of bonds and bills, the State will likely-and should

\footnotetext{
${ }^{53}$ For a good overview of this function in the United States, see Hillery, P., and Thompson, S., The Federal Reserve Banks as Fiscal Agents and Depositories of the United States, Federal Reserve Bulletin, Vol. 86, 2000, 251-259.

${ }^{54}$ These three roles are closely intertwined: see DeCorleto, D., and Trimble, T., Federal Reserve Banks as Fiscal Agents and Depositories of the United States in a Changing Financial Environment, Federal Reserve Bulletin, Vol. 90, Nr. 4, 2004, 435-446.

${ }^{55}$ For instance, important variables that are typically included in the central bank law are: (i) whether the State is allowed or required to hold its cash balances in the books of the central bank; and (ii) in case of the latter, whether the State must hold all its cash in the books of the central bank or whether it can have recourse to other depositaries. The central bank law may also determine whether or not the fiscal agency services will be provided gratis or against a fee. For a general overview, see: Addo Awadzi, E., o.c., "Box 6: Key Features of a Fiscal Agency Agreement for Public Debt Management."
} 
actually-be responsible, through the MoF, for announcing the auction calendar and determining the cut-off prices for the bids in the auctions. ${ }^{56}$

95. A clear delineation of roles instills confidence among market participants in the structure and modus operandi of the primary market and contributes to the overall transparency of the market structure. This also pleads in favor of publishing the Fiscal Agency Agreement, which is still not done by many central banks.

\section{ConcLusions}

96. The development of an efficient and effective LCBM is a critical step to deepening a country's capital market and will also serve to support a country's macroeconomic performance and financial stability. A well-developed LCBM can increase a country's ability to respond to shocks and absorb volatile capital flows (such as those recently experienced in response to the COVID-19 pandemic), while also enabling the financial sector to effectively manage liquidity in a way that contributes to greater banking sector stability. In this regard, putting in place robust legal and tax frameworks to support an effective and efficient LCBM cannot be underemphasized because of these impacts (as also recognized as part of the ongoing G20 agenda on LCBM development).

97. While recognizing that there is no one size fits all approach, this Working Paper has outlined a strategically anchored methodology that can be applied to strengthen the relevant legal and tax foundations of LCBMs given that these foundations are critical to the development of LCBMs. Countries should ensure:

- At the level of the government (as an issuer of debt securities), that their legislation and other legal instruments (e.g., a fiscal agency agreement between the State and the central bank) clearly stipulates:

The ability of the government (and other public entities as appropriate) to borrow and the authorization of different government entities to operate in these markets; and

$>$ Provides for effective monitoring, reporting, and accountability mechanisms for the above activities.

- $\quad$ The legal framework underpinning LCBMs should:

$>$ Provide for settlement finality for payment and security transfers, which must be effective to protect such finality from risks stemming from insolvency and other laws;

${ }^{56}$ Addo Awadzi, E., o.c., Box 6. 
Protect against other known legal risks associated with "financial collateral" by ensuring that the legal framework has critical features relating to ownership rights over the collateral, close-out netting and operational flexibility (e.g. right of substitution), which can also be combined with the settlement finality legislation (above) in a single instrument;

> Support the legal status of the dematerialization of securities through adequate securities holding legislation, by specifically recognizing security ownership through credit balances in securities accounts (kept as electronic records) rather than through physical holding;

Provide adequate investor protections such as mandating the segregation and safekeeping of assets and prohibiting the use of client assets without their consent (which could also be designed and implemented in a manner that builds upon the securities holding legislation);

Provide (through regulations) a sound legal basis for the organization of the primary and secondary markets in government securities, which should be developed around three distinct but complementary objectives: (i) maintaining fair, efficient and transparent markets; (ii) reducing systemic risk; and (iii) protecting investors. These regulations should be effective, for example, to prohibit and sanction inappropriate behavior by custodians (for instance, misuse of client assets) and intermediaries (from instance, from improper trading practices, such as market manipulation and insider trading); and

$>$ Ensure any contractual framework for government debt securities (for instance, $\mathrm{T} \& \mathrm{Cs}$ ) is robust, which should be exclusively governed by the law of the issuer, to the exclusion of any foreign law element.

- The tax law framework must also be appropriate for the development and efficient working of the LCBM by encouraging investment and liquidity in bond markets. Countries should ensure they cover:

$>$ The supply side of LCBs (dealing with the tax treatment of the LCBs themselves in both the primary and secondary markets). This should include clear and certain rules for the tax treatment of returns from LCBs (e.g. interest, discount, maturity amounts, treatment of gains on sale), as well as the tax treatment of other key secondary market transactions such as repos, securities lending, financial collateral, and derivative transactions; and

$>$ The demand side of LCBs (dealing with the effective and efficient alignment of that tax treatment between key institutional investor groups, including mutual, pension and investment funds, to encourage investment and liquidity in LCBMs);

- Importantly, a clear and effective tax treatment for each key class of investor that conforms to international good practices is critical, especially for foreign investors, 
given the tax conditions often becomes essential to establishing critical links between LCBMs and international FMIs. As discussed extensively in Sections VI and VIII, it is common international practice for a more generous tax treatment to apply for nonresidents investing in LCBs comprising government debt securities (for instance, nonimposition of interest withholding tax, and exemption from tax on gains on those LCBs). 


\section{AnNeX I: CASE STUdY-GeORgia}

1. The IMF's Legal Department, in coordination with the Monetary and Capital Market Department, has provided significant TA support with respect to the development of capital markets in Georgia, including the LCBM. More specifically, in Georgia, the IMF's Legal Department continues to support the authorities to develop a set of financial and fiscal legal instruments that will underpin the development of local currency bond markets and develop their capital market more broadly. This ongoing TA builds on the law reform support already provided to date (e.g. payment systems law, securities holding legislation and tax law framework for financial instruments and investment funds) and will involve the development of: (i) an improved contractual framework for government debt securities; (ii) a master securities lending agreement; (iii) a MoF-NBG fiscal agency agreement; (iv) a PDs legal framework; and (v) a tax law framework for private equity and the insurance sector.

2. The purpose of this case study is to discuss the Georgian example as a good example of sequencing the law reforms in a manner consistent with the guidance in the GN. More specifically, by starting with the primary market, then covering secondary market transactions, and, once completed, moving to the critical demand side reforms (such as investment funds, pension funds, insurance sector etc.). IMF TA support was more intensive with secondary market transactions (e.g. secondary sales, repos, securities lending, financial collateral and derivatives etc., which follows international best practice) as well as with investment funds (to ensure tax neutrality when investing in securities).

3. By way of background, increasing access to finance was a key objective of Georgia's Social-Economic Development Strategy entitled “Georgia 2020”. In Georgia 2020, the Government identified increased access to finance as a key objective to increase business development, productivity and exports, so as to achieve the necessary rate of investments in the economy. Inefficient financial intermediation was identified as a main barrier for achieving this objective. ${ }^{57}$ In this regard, the underdevelopment of capital markets in Georgia was identified as a serious problem.

4. It is in this context that the authorities of Georgia released in April 2016 their Capital Market Development Strategy and Action Plan (Capital Markets Plan). The Capital Markets Plan aimed to deepen the capital markets of Georgia. The Capital Markets Plan was drafted as part of a yearlong working process of the interagency group specifically created for this task by the Prime Minister of Georgia. In this regard, the Plan represented a unified vision and approach of the NBG, MoF, MESD and other stakeholders and market participants. The Capital Markets Plan identified a number of impediments to the

\footnotetext{
${ }^{57}$ The other main impediment identified by Georgia 2020 is the low savings rate. This was proposed to be addressed, inter alia, through pension reform by introducing a mandatory pension savings scheme. The Georgian pension law reform became effective in 2019.
} 
development of capital markets in Georgia, which included unsatisfactory legal and regulatory frameworks, particularly in relation to taxation.

\section{One primary area of focus of the authorities was to reform the tax law} framework as it relates to Georgia's primary and secondary bond markets. The authorities reviewed their existing tax law framework to identify areas for reform and designed and drafted a set of tax law measures to better support the Government's policy objective of deepening domestic capital markets, including LCBMs. This led to the enactment of various packages of tax law reforms that focused initially on the "supply side" of LCBs (dealing with the tax treatment of the LCBs themselves in both the primary and secondary markets), and then moved to address the "demand side" of LCBs (dealing with the effective and efficient alignment of that tax treatment between key institutional investor groups, including mutual and investment funds, to encourage investment and liquidity in LCBMs). A summary of the reforms that Georgia has implemented to create a competitive tax law framework for investors in Georgia's primary and secondary bond markets, particularly foreign investors, can be found at Box A below.

\section{Box A. Recent Tax Law Reforms in Georgia-Enacted Tax Law Reforms}

\section{Package 1 (Rates and concessions)}

LCBs in the form of government debt securities benefit from tax exemptions on income and capital gains for non-resident investors. This was extended by Package 1 to qualifying corporate bonds that meet stricter eligibility criteria.

\section{Package 2 (Technical amendments)}

Technical amendments to remove tax impediments and provide investor certainty, covering:

- Secondary sales (split between capital and interest component);

- Taxation of repos (consistent with section VIII);

- Taxation of securities lending (similar to repos);

- $\quad$ Treatment of financial collateral (similar to repos); and

- Taxation of derivatives (mark-to-market).

6. Following the successful completion of the above tax law reforms, the authorities finalized the design of a tax regime for investment funds. Investment fund investors are also expected to become integral to deepening the capital markets of Georgia, as they constitute a critical component of the demand side of the bond market. More specifically, the authorities have implemented a tax law framework for investment funds ${ }^{58}$ that: (i) uses legal

\footnotetext{
${ }^{58}$ The parliament of Georgia passed the amendments to the Tax Code of Georgia (along with the Law of Georgia on Investment Funds) in July 2020 and these amendments entered into force on October 19, 2020. In
} 
structures that are familiar to investors, drawing also on overseas experience in other jurisdictions to inform the tax law design of the regime; (ii) achieves tax neutral outcomes for investors (same or better treatment than direct investments); (iii) provides flexibility to cater for the needs of different investors (e.g. tax treaty entitlements); (iv) ensure no local taxation of conduit foreign income; and (v) maximizes certainty and simplicity. In due course, the authorities are also expected to focus on developing more effective and efficient tax law rules for other key institutional investor groups such as insurance companies.

\section{Georgia now has a tax law framework that provides clear, internationally} comparable, rules for determining the tax treatment of returns from LCBs (e.g. interest, discount, maturity amounts) in the hands of all key classes of domestic and foreign investor (retail and institutional). Similarly, the reforms brought about much needed certainty with respect to the tax treatment of secondary market transactions over LCBs (such as the tax treatment of gains on secondary sale for both retail and institutional investors, as well as repo, securities lending, financial collateral, and derivative transactions for institutional investors). In the context of facilitating foreign investment, interest withholding tax and capital gains tax concessions/exemptions in relation to returns and gains on publicly issued bonds were implemented (see Box A above) that were consistent with international common practice, and have been effective to support the continued establishment of critical investment links between Georgia's bond market and Clearstream. ${ }^{59}$ Additionally, the further work to design and implement a tax law framework for investment funds has led to an internationally competitive set of rules that are aimed at attracting local and foreign investment into local domiciled CISs by achieving tax neutral outcomes for those investors.

\section{However, given these implemented and prospective tax law reforms are new} (and being accompanied by a set of broader capital market reforms), it is expected to take some time before the full benefits accrue in terms of being able to measure the results on encouraging investment and liquidity in LCBMs. However, the recent efforts to remove the tax law impediments and create a competitive tax law framework for all key classes of investors, including non-residents, has created conducive legislative conditions to further the aim of deepening the Georgian LCBMs.

\footnotetext{
addition, under the amendments, the NBG and MoF are expected to promulgate a joint regulation governing opening and maintenance of investor accounts for unit-holders in common funds.

59 https://www.clearstream.com/clearstream-en/products-and-services/market-coverage/europe-non$\underline{\mathrm{t} 2 \mathrm{~s} / \text { georgia/market-link-guide-georgia-1281410 }}$
} 


\section{REFERENCES}

Addo Awadzi, E., "Designing Legal Frameworks for Public Debt Management", IMF, WP/15/174, (Washington, 2015).

Bossu W., and Addo Awadzi E., "Private Law Underpinnings of Public Debt Securities Markets," Uniform Law Review, 2013 Vol. 18, 2013, 564-588, Oxford Journals/Oxford University Press, (Oxford, 2013).

DeCorleto, D., and Trimble, T., 2004, "Federal Reserve Banks as Fiscal Agents and Depositories of the United States in a Changing Financial Environment", Federal Reserve Bulletin, Vol. 90, (Washington, 2004).

Elizalde, H., The International Monetary Fund and Current Account Convertibility in: Current Developments in Monetary and Financial Law, Vol. 4, 2005, pp. 17-40.

Guynn, R., 1996, “Modernizing Securities Ownership, Transfer and Pledging Laws-A Discussion Paper on the Need for International Harmonization", International Bar Association, (IBA, 1996).

Hillery, P., and Thompson, S., 2000, “The Federal Reserve Banks as Fiscal Agents and Depositories of the United States", Federal Reserve Bulletin, Vol. 86, (Washington, 2000).

IFC, EM Compass, Creating Domestic Capital Markets in Developing Countries: Perspectives from Market Participants.

International Monetary Fund (IMF) and World Bank Group (WBG), 2020, "Staff Note for the G20 International Financial Architecture Working Group (IFAWG)-Recent Developments on Local Currency Bond Markets in Emerging Economies”, (Washington, 2020).

International Monetary Fund (IMF) and World Bank Group (WBG), 2020, “Guidance Note for Developing Government Local Currency Bond Markets”, (forthcoming).

International Monetary Fund (IMF), World Bank, European Bank for Reconstruction and Development (EBRD), and Organization for Economic Cooperation and Development (OECD), 2013, "Local Currency Bond Markets-A Diagnostic Framework", (Washington, 2013).

International Monetary Fund (IMF), "Decision No. 15203-(12/72)”, July 18, 2012 in IMF, 2019, Selected Decisions, p. 10 at https://www.imf.org/external/SelectedDecisions/Description.aspx?decision=15203$(12 / 72)$.

International Monetary Fund (IMF), "Decision No. 1034-(60/27)", June 1, 1960 in IMF, 2019, Selected Decisions, p. 516 at https://www.imf.org/external/SelectedDecisions/Description.aspx?decision=1034$(60 / 27)$. 
International Monetary Fund (IMF), 2010, The Fund's Mandate-An Overview, (Washington, 2010).

International Monetary Fund (IMF), 2012, Modernizing the Legal Framework for Surveillance-An Integrated Surveillance Decision (Washington, 2010).

International Monetary Fund (IMF), 2012, "The Liberalization and Management of Capital Flows: An Institutional View”, (Washington, 2012).

International Monetary Fund (IMF), 2012, "Strengthening the Contractual Framework to Address Collective, Action Problems in Sovereign Debt Restructuring," (Washington 2014).

International Monetary Fund (IMF), 2020, "The International Architecture for Resolving Sovereign Debt Involving Private-Sector Creditors-Recent Developments, Challenges, And Reform Options," (Washington 2020).

Kronke, H., The Draft Unidroit Convention on Intermediated Securities: Transactional Certainty and Market Stability.

Leckow, R., Rendak, N., and Strauss, M., Currency Controls, Max Planck Encyclopedia of Public International Law (2014).

Thevenoz, L., Intermediated Securities, Legal Risk, and the International Harmonisation of Commercial Law, Duke Law School Legal Studies Paper No. 170.

Wendt, F., Katz, P., and Zanza, A., 2018, "Organizing Central Securities Depositories in Developing Countries-Seven Considerations", IMF, WP/18/66, (Washington, 2018). 